\title{
العبادات بين التعليل والتعبُّد: مقاربة أصولية
}

\section{جميلة تلوت}

$$
\begin{aligned}
& \text { الملنص } \\
& \text { يعدّ إشكال تعليل العبادات من المسائل المختلف فيها قديماً وحديثاً، ويتعزز الإشكال أكثر مع إعلان الشاطبي } \\
& \text { بأن أحكام الله تعالى تعلل بالمصالح، الأمر الذي يثير السؤال الآتي: كيف يمكن القول إن أحكام العبادات غير معللة، } \\
& \text { وإن الأصل فيها التعبُّد؟ بأب } \\
& \text { هذا هو محل الإشكال في البحث، لذلك عملت على مقاربته منهجياً، بدءاً من تحديد المفاهيم، ثم ذكر الخلاف } \\
& \text { الأصولي في المسألة، وتحرير محل النزاع وبيان أدلة الآراء، ثم بيان أثر الخلاف في ذلك على الخلاف الفقهي في عدد من من من } \\
& \text { المسائل العبادية، وأخيراً اقتراح مداخل التجاوز بانتهاج مقاربة تغلب النظر المقصدي. }
\end{aligned}
$$

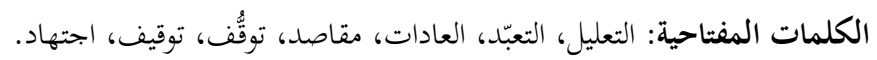

\section{Islamic Acts of Worship between Rationalization and Ritualization: An Ușūlī/Theoretical Approach}

Abstract

The rationalization in the Islamic acts of worship is a problematic issue, especially since al-Shātibī has proclaimed that all Sharī'ah provisions are rationalized in terms of what is good for people. The question that needs to be answered is: how can it be said that acts of worship are not necessarily rationalized, and that they are based on ritual obedience?

The article tries to approach the issue methodologically, starting from defining the concepts, stating the different opinions on the issue, clarifying the heart of the debate, and tracing the effects of this Ușūli disagreement on the fiqhi disagreement in a number of worship issues. Finally, the article suggested a maqāsidī approach to go around this problematic issue.

Keywords: rationalization; ritualization; workships; habits; jurisprudence; purposes, ijtihād.

$$
\begin{aligned}
& \text { باحثة في الدراسات الأصولية والمقاصدية، طالبة باحثة في سلك الدكتوراه: مختبر الدراسات الدينية والعلوم المعرفية }
\end{aligned}
$$

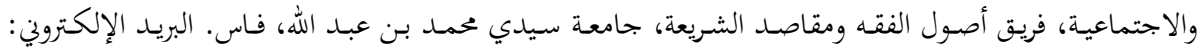

$$
\begin{aligned}
& \text { jamila.tilout19@gmail.com }
\end{aligned}
$$

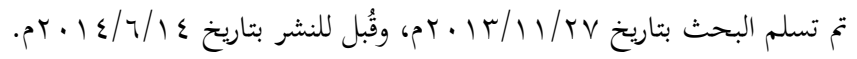




\section{مقدمة:}

عـرف أواخـر القــرن الماضـي بدايـة ثـورة مقاصـدية شـكّل أسسـها النظرُ في الـدرس

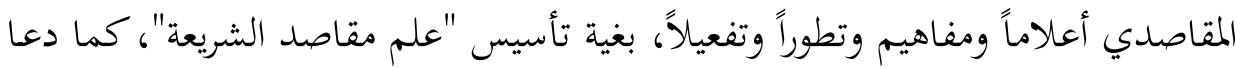

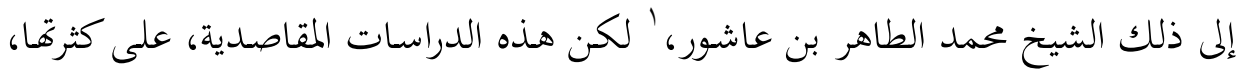

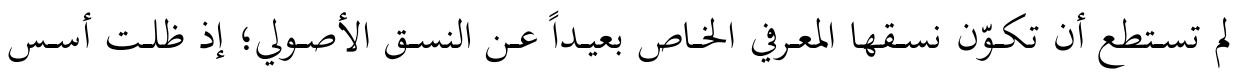

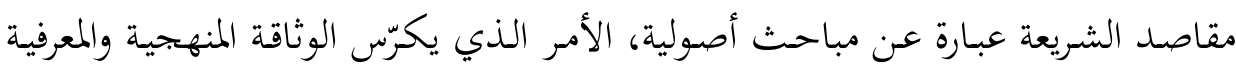

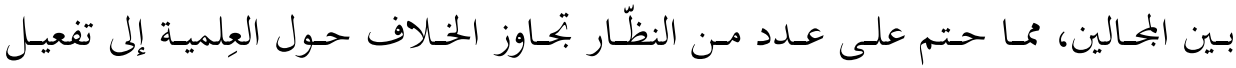

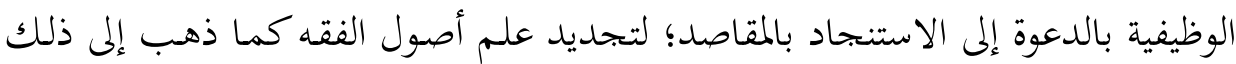

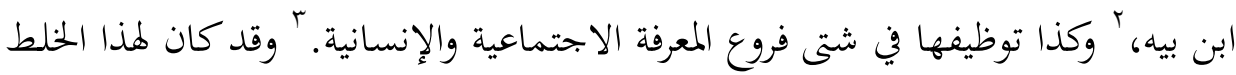

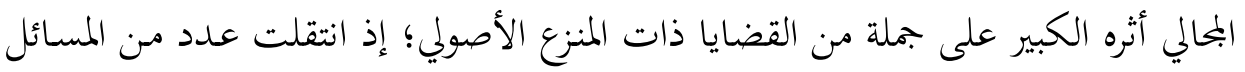
الأصولية إلى الاستشكال في الدرس المقاصدي المعاصر. ومن بين المسائل المشكلة التي تمت إثارتا، إشكال تعليل العبادات، والخلاف الذي

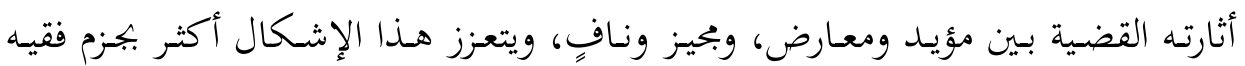

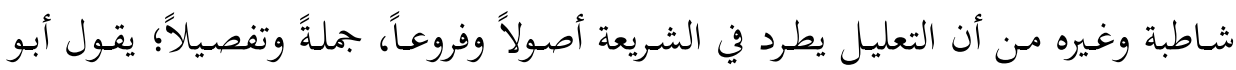

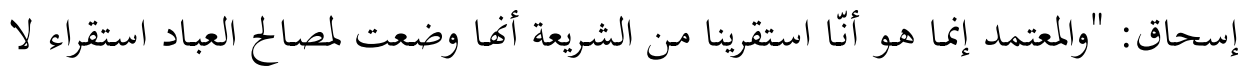

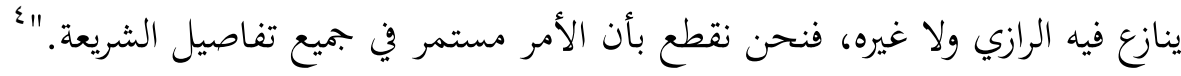

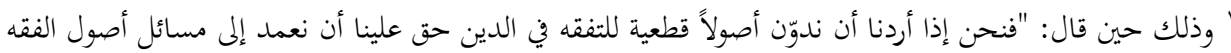

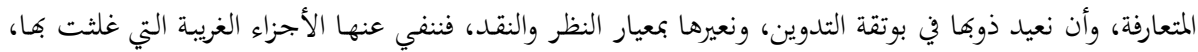

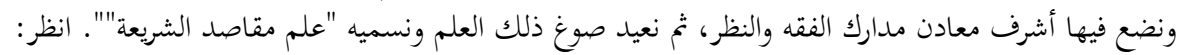

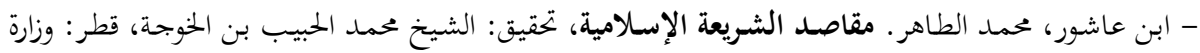

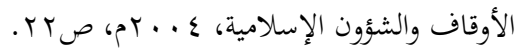

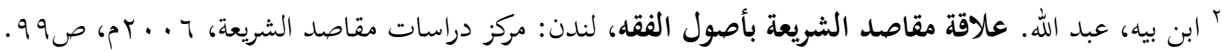

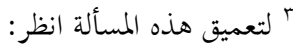
- النعيم، عبد الله. مقاصد الشريعة: نحو إطار للبحث في العلوم الاجتماعية والإنسانية، دمشق: دار الفكر،

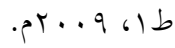

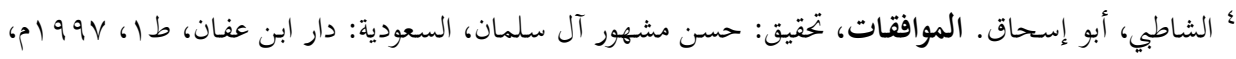




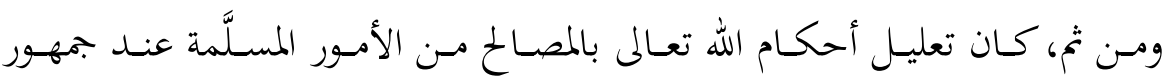
العلماء؛ إذ كانت محل اتفاق وإجماع، وقد صرح بهذا الإجماع غير واحد من الأصوليين،

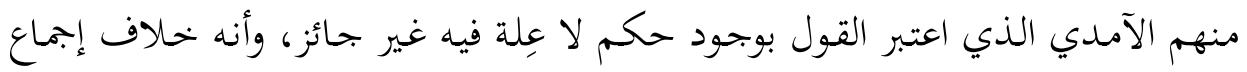
الفقهاء على أن الحكمى لا يخلو من عِلّة.

فإذا كان هذا الأمر مستمراً في جميع تفاصيل الشريعة وأحكامها كما قال الشاطبي، وحكى بعضهم الإجماع على ذلك، فكيف يمكن القول إن أحكام العبادات غير معللة، وأن الأصل فيها التعبُّد؟ بعص؟ الإعاع

فهـذا هـو محـل الإشـكال في البحـث، لـذلك عملـت على مقاربتـه وفـق منهجيـة

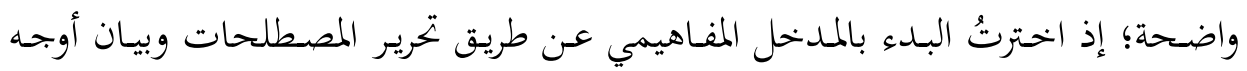

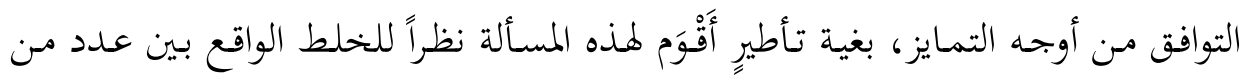

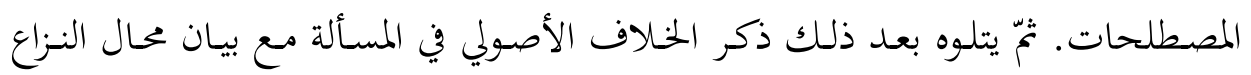

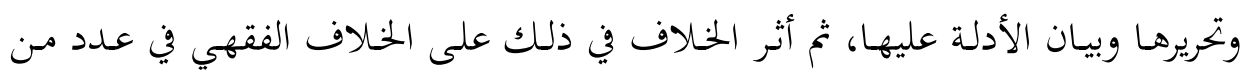

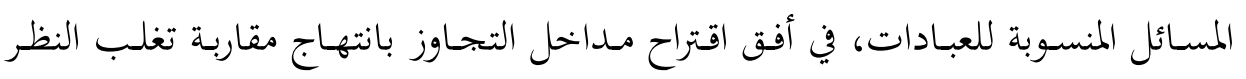
المقصدي.

وألمح هاهنا أن البحوث التي قاربت المسألة متعددة ومختلفة الأبعاد؛ فمنها البحوث

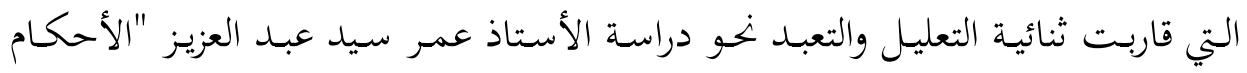

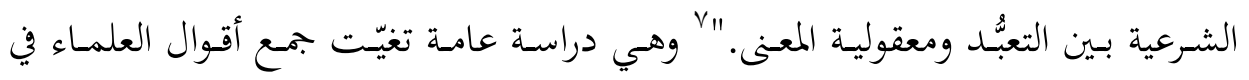

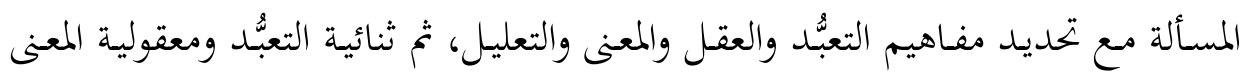

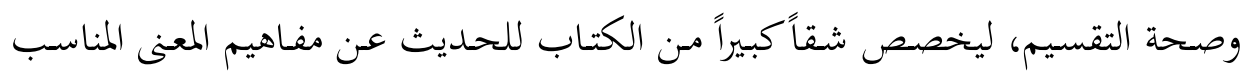

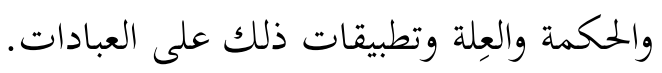

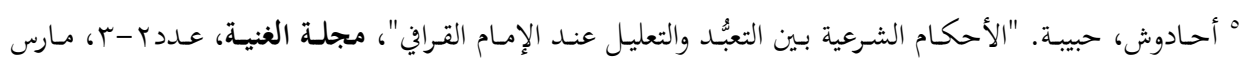

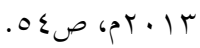
" الآمدي، علي بن محمد. الإحكام في أصول الأحكام، تحقيق: سيد الجميلي، بيروت: دار الكتاب العربي، طا،

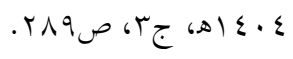

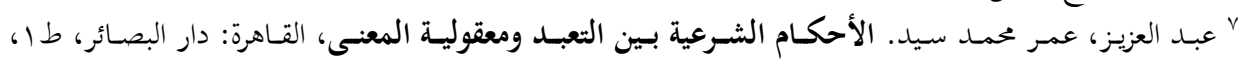




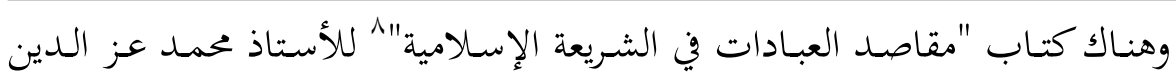

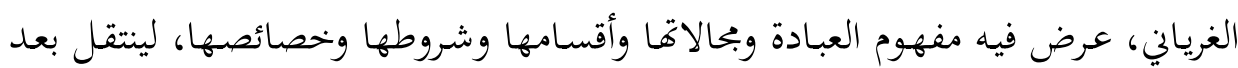

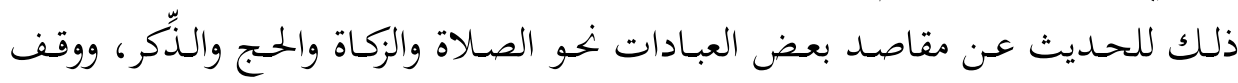

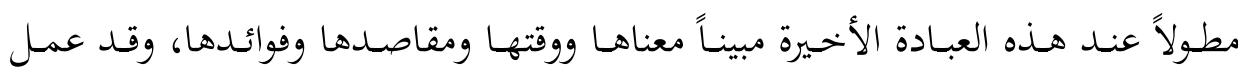

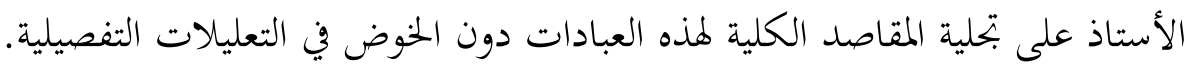

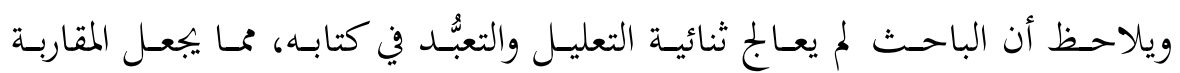

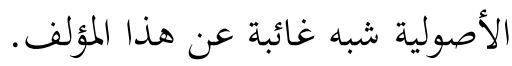

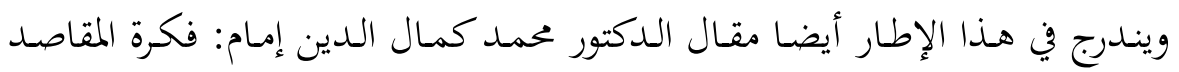

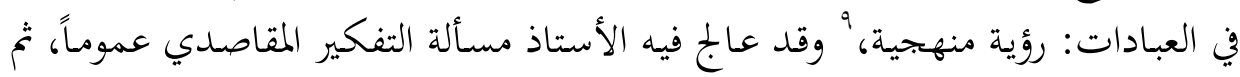

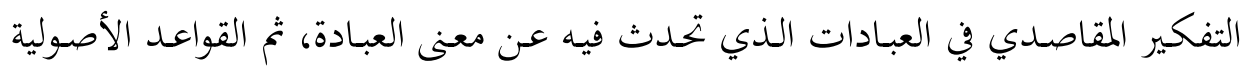

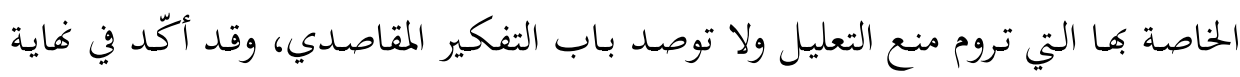

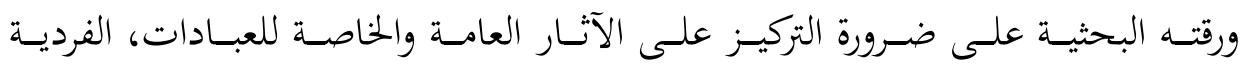

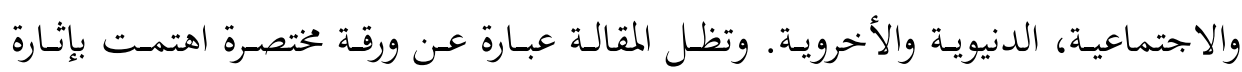

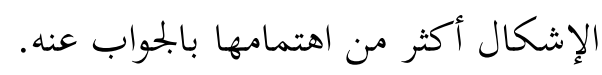

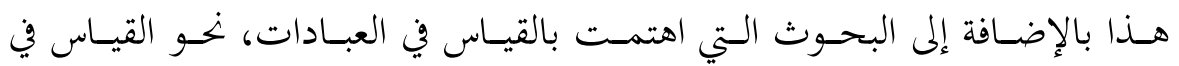

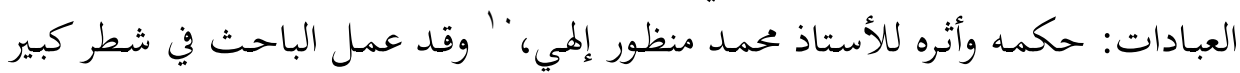

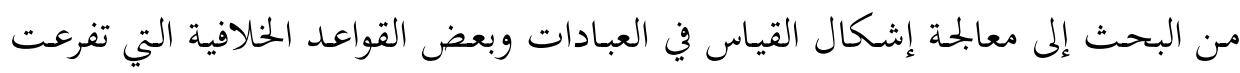

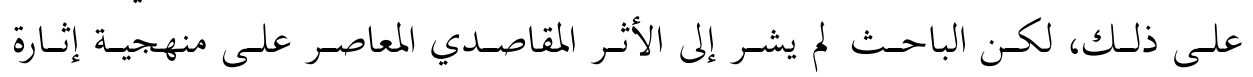

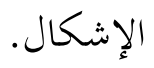

فهذه هي بعض البحوث وليست كلها، والتي رأيت بعد النظر وإعادته أها لم تحاول

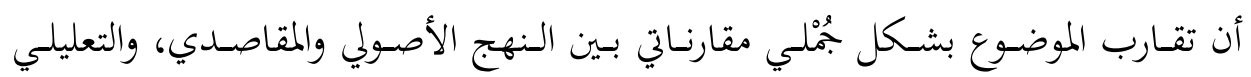

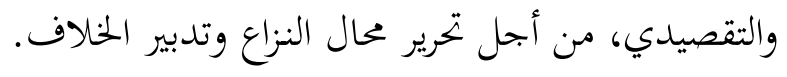

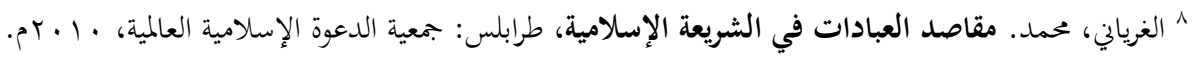

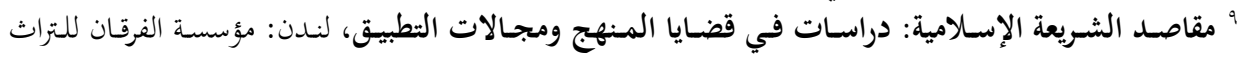

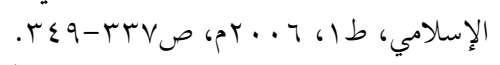

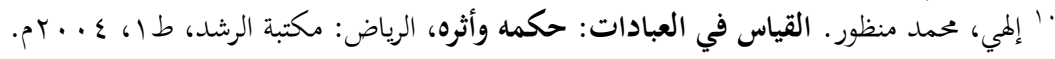




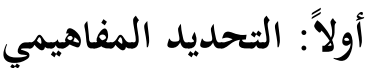

لماكان المدنحل المفهومي الباب الأول للولوج المنهجي لضبط الإشكال وتحديده،

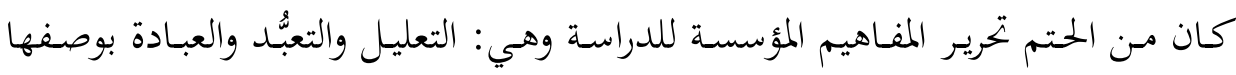

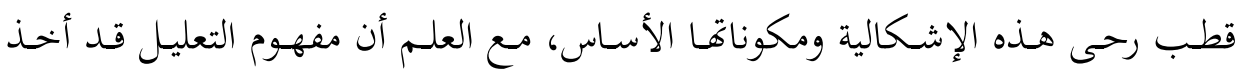

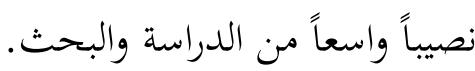

وبتحر الإشـارة إلى أني لن أوجها البحث صوب الأسس الكلامية لنظرية التعليل،

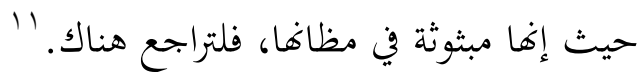

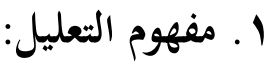

دُرس هذا المفهوم كثيراً في شتى التواليف، والعديد من هذه الدراسات اشتغلت على الى الدي

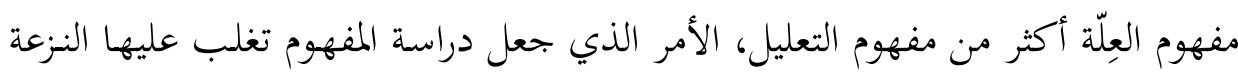
الكلامية بدل المعالجة العلمية وفق المقاربة الأصولية.

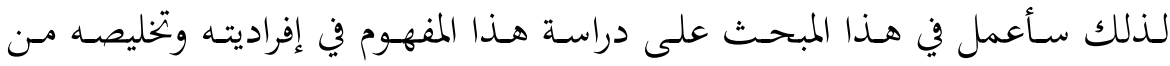

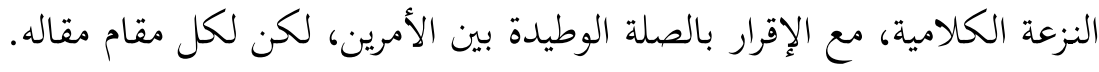

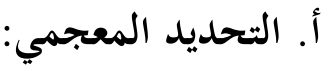

التعليل في اللغة مصدر "علهّ" علل يعلل تعليلاً ولا يكون إلا بعِلة، وعليه كانت

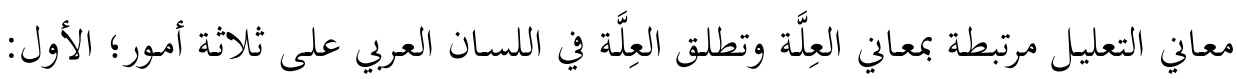

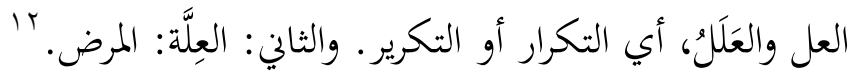

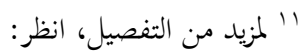

- بزا، عبد النور. نظرية التعليل في الفكرين الكلامي والأصولي، فرجينيا: المعهد العلمي للفكر الإسلامي،

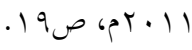

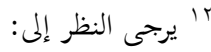
- ابن فارس، أممد. معجم مقاييس اللغة، تحقيق: عبد السلام هارون، سوريا: دار الفكر، 9V9 (م) باب: العين 


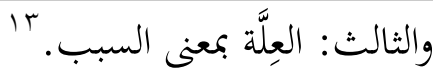

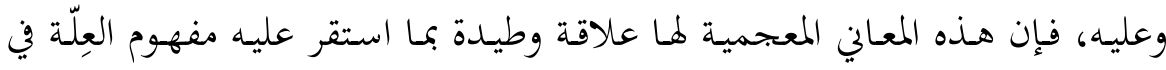

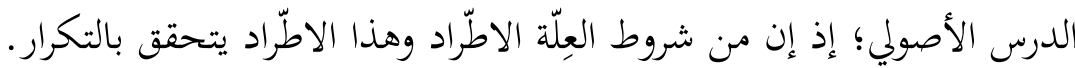
كما أن من يقول بأن العِلَّة مؤثرة فإن معنى التغير يلحقها أيضاً، حيث إن العِلَّة تؤثر

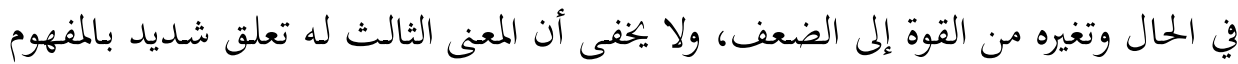

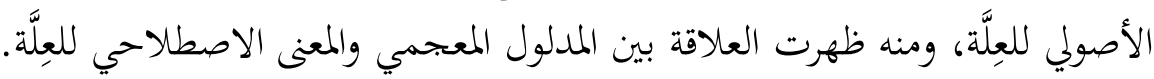
وإذا مـا تأملنـا الصـيغة الصـرفية للكلمـة نلحظظ أفها صـيغت على وزن "تفعيل " مـن

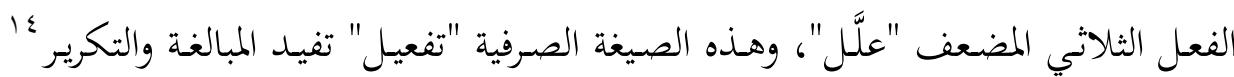

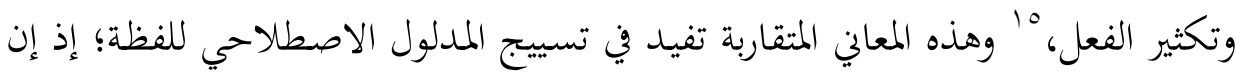

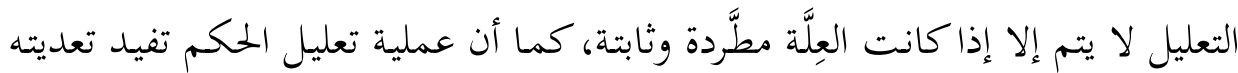
في أكثر من ححل، وهذا ينسجم مع الاشتغال الوظيفي للمفهوم في الحقل الأصولي.

\section{ب. التحديد المصطلحى:}

أول ما يشار إليه في بداية هذا المطلب أن التعليل والاعتلال في الاصطلاح الأصولي

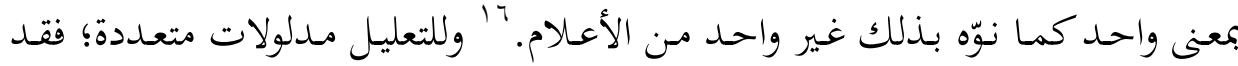

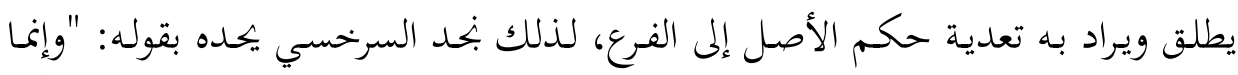

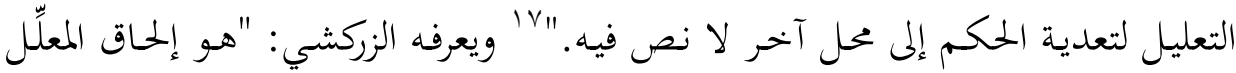
- الجوهري، الصحاح، تحقيق: أحمد عبد الغفور عطار، بيروت: دار العلم للملايين، طع، 9AV ام، مادة: عل وعلل. - الزبيدي، محمد بن محمد. تـاج العروس مـن جـواهر القاموس، تحقيق: بحموعة من المحققين، الكويت: دار الهداية، د.ت.

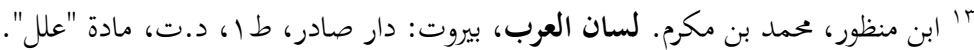

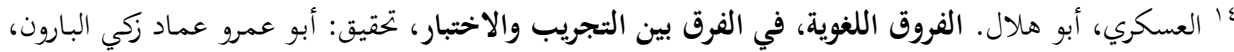

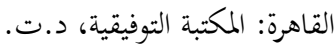
10 المرجع السابق. '1 الزركشي، بدر الدين. البحر المحيط، تحقيق: محمد محمد تامر، بيروت: دار الكتب العلمية، .. .بمه، ج؛، ص. 111. r' السرخسي، محمد بن أحمد. أصول السرخسي، بيروت: دار الكتاب العلمية، ط1، ب99 امج، جr ص109. 
الفرع بالأصل بالعِلّة المقتضية لذلك،" "1الوهذا هو المعنى الذائع والفاشي لمفهوم التعليل. ونلحظ أن هذا المدلول له تعلّق قوي بدلالة القياس كما يظهر، وإن كان مفهوم القياس ينبني أصالة على وجود التعليل. وهناك من يُغلِّب البُعد الكشفي لمفهوم التعليل؛ أي إظهار عليّة الشيء سواء كانت

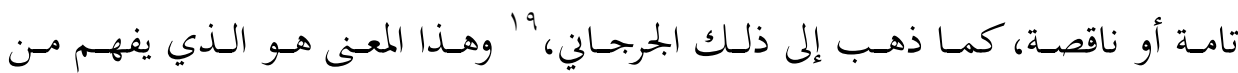
استعمالات أبي إسحاق، فالتعليل عنده هو بيان وجه الحلكمة في الحلكم، من مصلحة أو إو

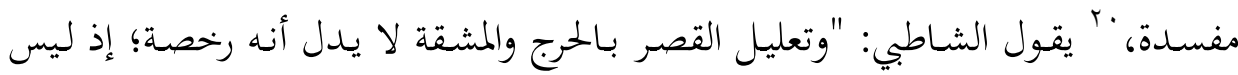
كل ما كان رفعاً للحرج يسمى رخصة على هذا الاصطلاح العام."'ب وقد مال المتأخرون

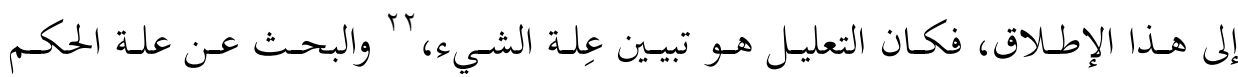
المنصوص عليه، والسبب الموجب له شرعاً أو قانوناً. بَّ وعرفه الأستاذ الغرياني: "التعليل

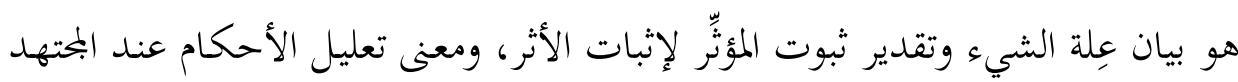

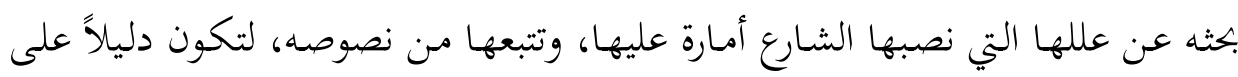

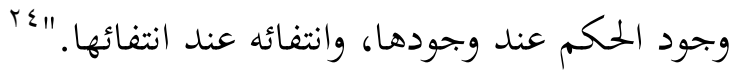

فالغرض من التعليل هو القياس أصالة، بْ لذلك بجد بعض المتقدمين عرّفوه بوصف وظيفته الأصولية العملية.

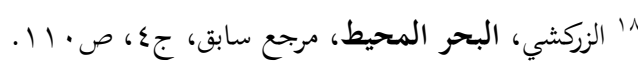

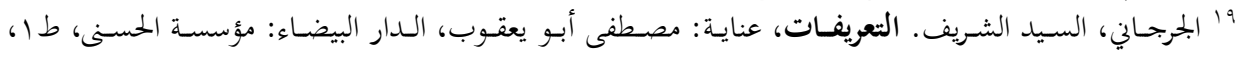

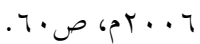

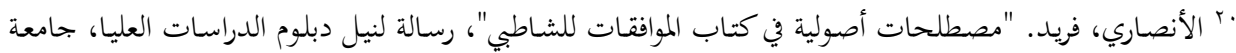

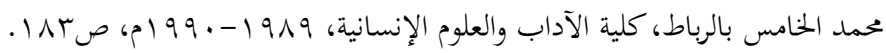

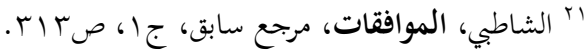

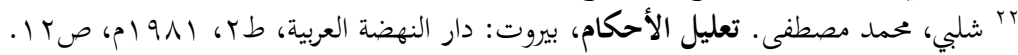

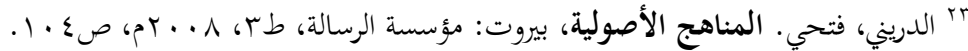

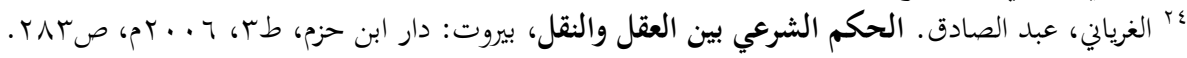

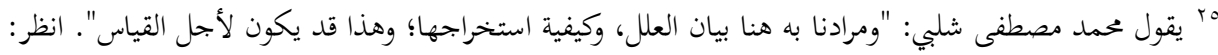

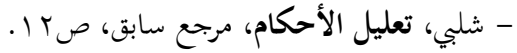




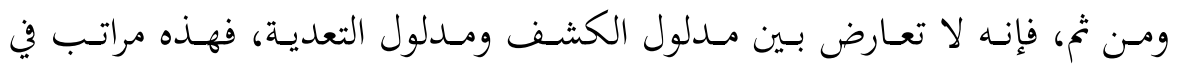

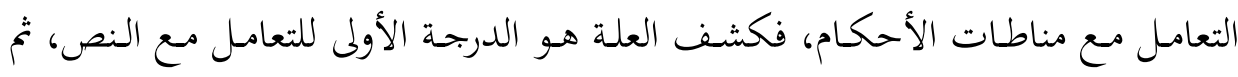
تتلوه عملية التعدية بمقتضياتا المعرفية.

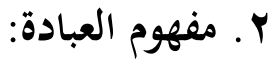

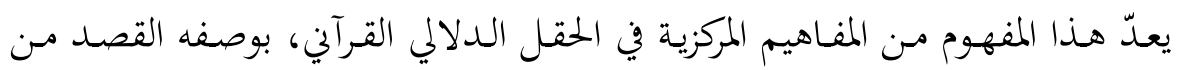

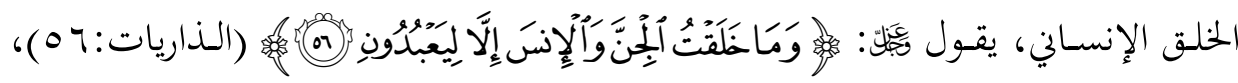

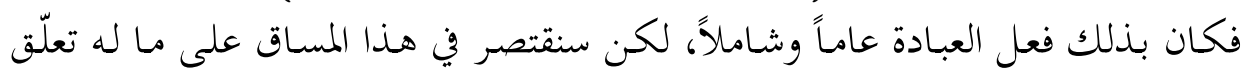
بإشكالية الدراسة.

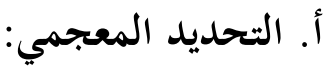

يقول ابن فارس: "العين والباء والدال أصلان صحيحان، كأغما متضادان، والأول

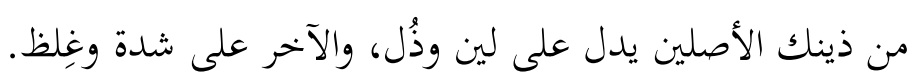
فالأول العبد، وهو المملوك، والجماعة العبيد، وثلاثة أعبد وهم العباد. قال الخليل:

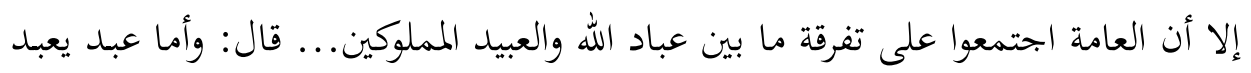

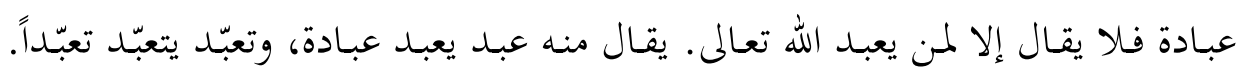

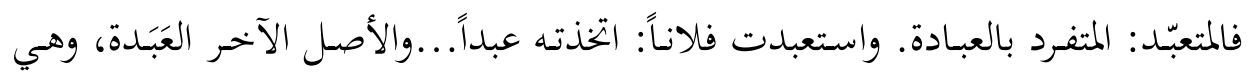

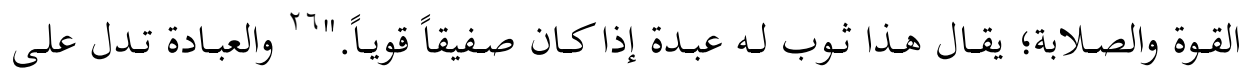
rV".الانقياد والخضوع.

ونلحظ من الصيغة الصرفية للكلمة "فِعالة" أهـا تسيّج مساحة المعنى؛ إذ يقصد بها القيام بالشيء^^مّا يدل على أن العبادة هي فعل يستلزم القيام به ظاهراً وباطناً. "ri ابن فارس، معجم مقاييس اللغة، مرجع سابق، مادة: عبد.

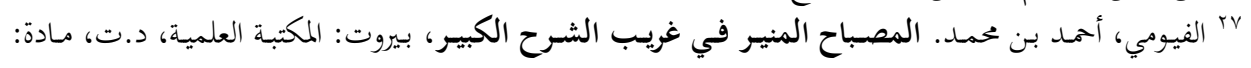
"عبد".

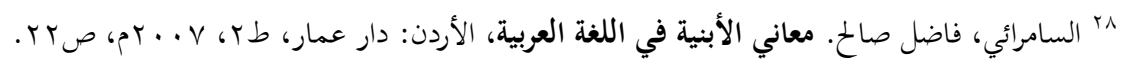


أما العبادة في الاستعمال القرآي فهي مصطلح عام، كما سبق ذكره، لكل ما يُنعبّد به. ويُفرق بين العبادة والعبودية، كما يقول الراغب بأن "العبودية إظهار التذلل، والعبادة فئل

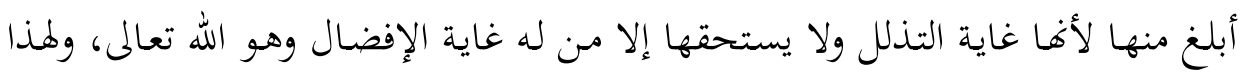

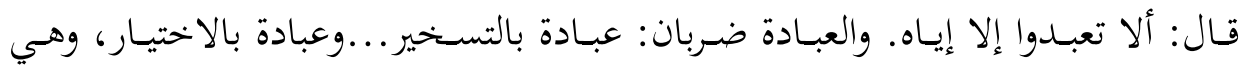

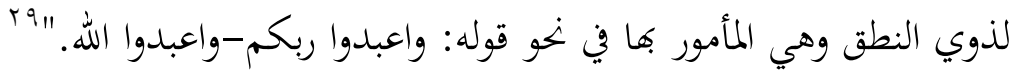
ومنـه، فـإن مفهوم العبـادة مفهوم شـامل؛ فهـي الانصـياع لأمـر الله جـل في عـلاه،

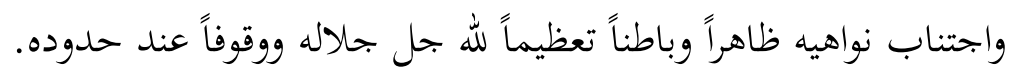

\section{ب. التحديد المصطلحي:}

والمقصود بـذلكم المحددات الأصسولية لمفهوم العبـادة، وبعد النظر في تـداوليات هـذا

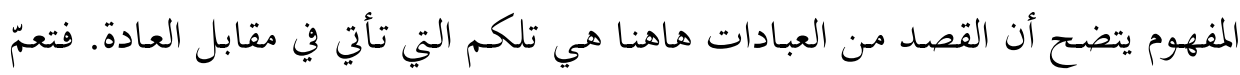

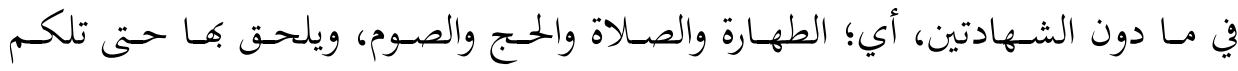

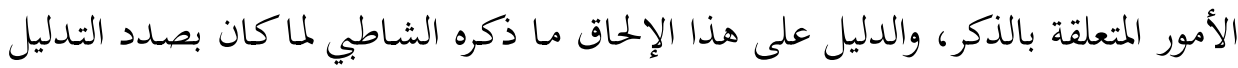

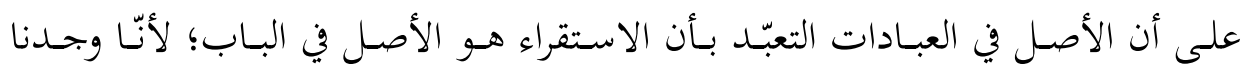

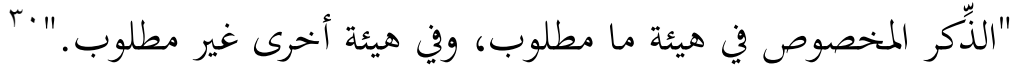
والضابط المشترك لما يندرج في مفهوم العبادة بالمدلول الأصولي، ضابط "التحديد"؛ أي تحديد الهيئة والطريقة التي لا يجوز الخروج عنها؛ لأن "المقصود الشرعي الأول التعبّد

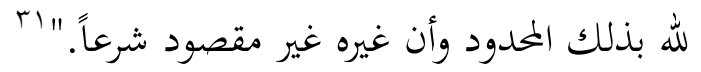

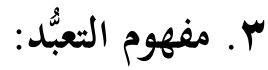

لماكان التعبّد يشترك في أصوله الدلالية اللغوية مع مفهوم العبادة، تمّ العدول عن

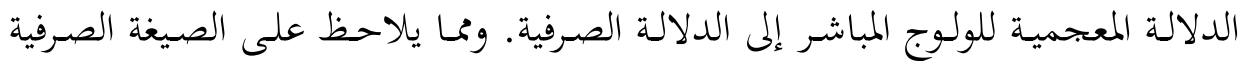
ج"r الأصفهاني، الراغب. المفردات في غريب القرآن، مراجعة: وائل أحمد عبد الرحمن، القاهرة: المكتبة التوقيفية، 


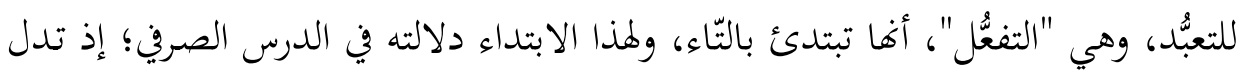

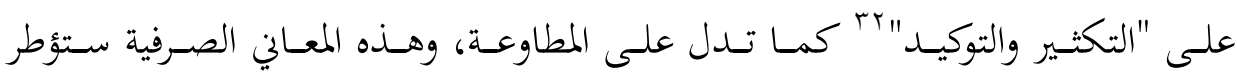

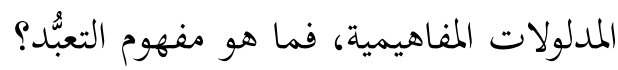

الناظر في الأدبيات الأصولية يجد أن التعبُّد يطلق بإطلاقين يجمعهما قول الشافعي:

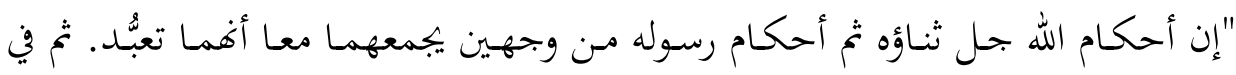

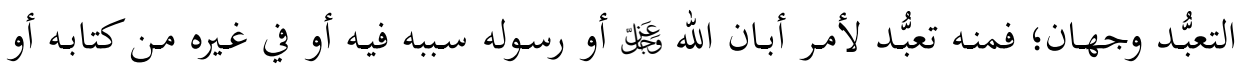

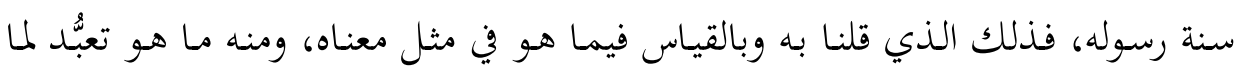

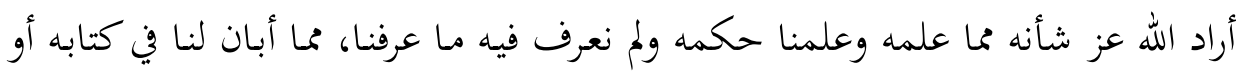

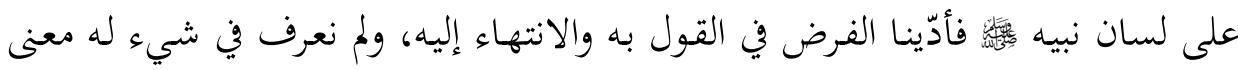

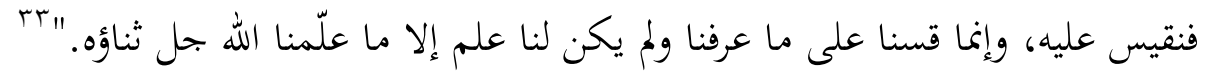

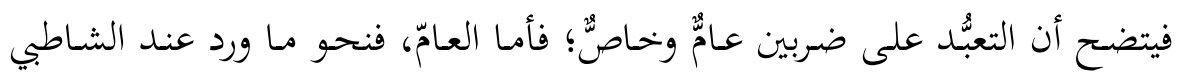

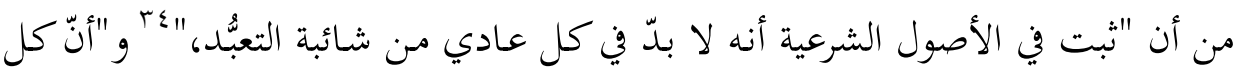

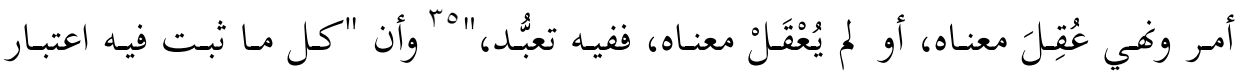

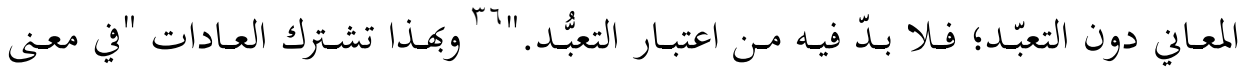

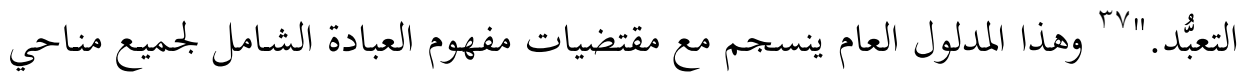
الحياة دون تمييز بين عاديات وعبادات.

أما الخاص، وهو الذي يسميه فقيه شاطبة بالتعبُّد المُض؛ فهو عامٌُّ في كل "ما لا

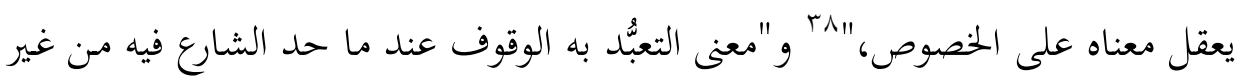
rr العكبري، أبو البقاء. اللباب في علل البناء والإعراب، تحقيق: غازي خختار طليمات، دمشق: دار الفكر، طا،

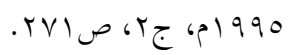

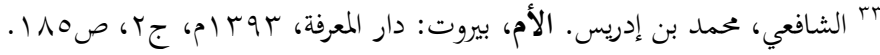

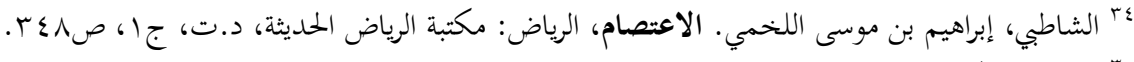

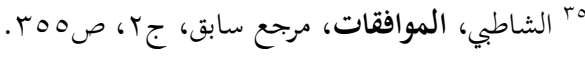

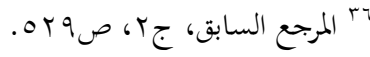
الش

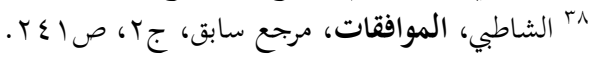




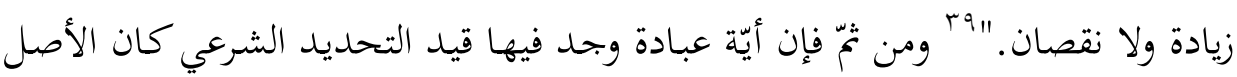
فيها التعبُّد حسب قول أبي إسحاق، ويراد به التوقُّف.

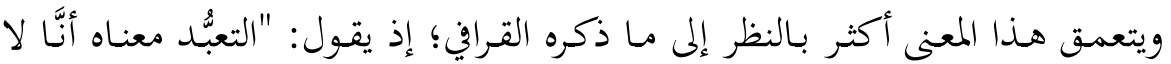

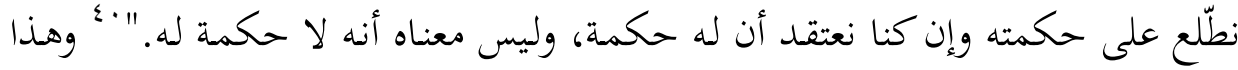

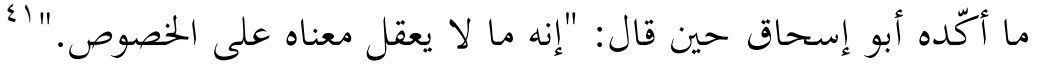

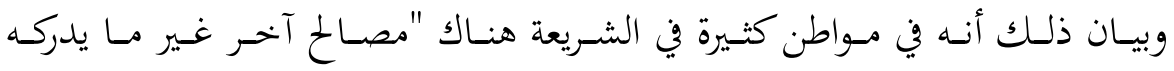

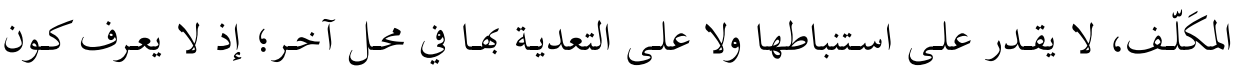

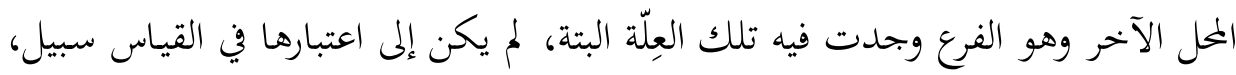

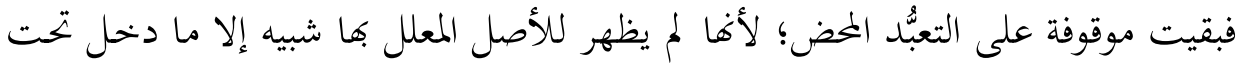

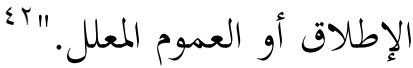

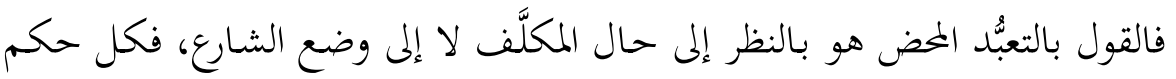

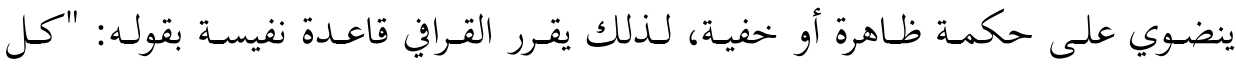

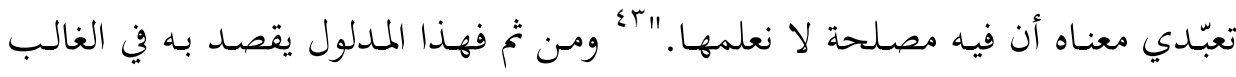

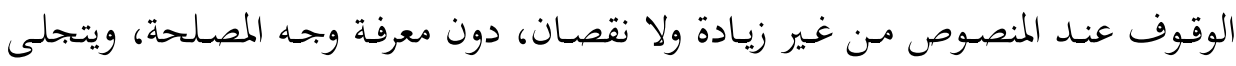

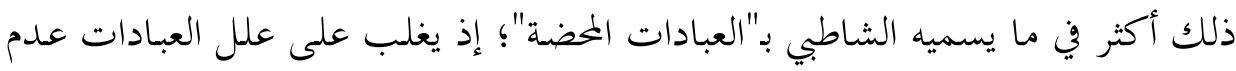

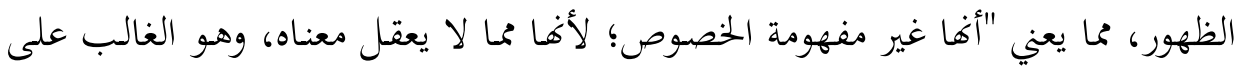

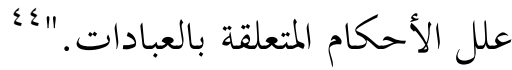

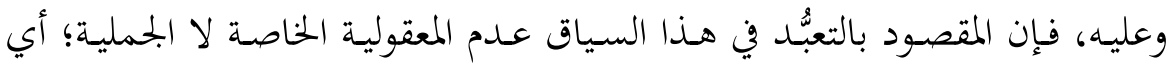

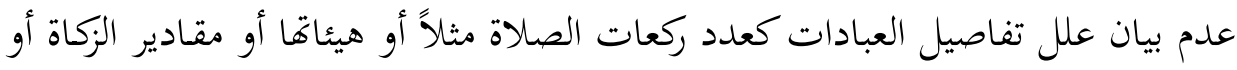
غير ذلك مما لا يدرك على الخصوص لعاص لا الجملة.

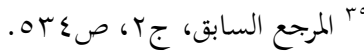

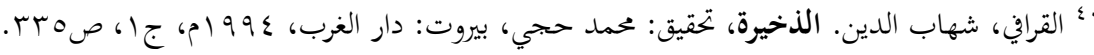

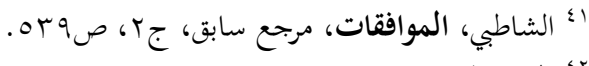

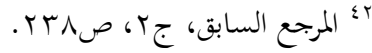

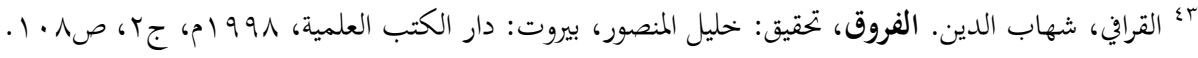

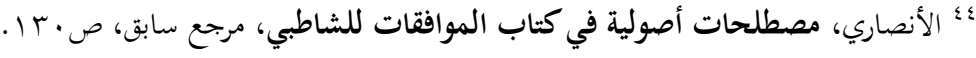




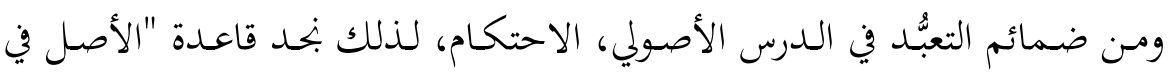

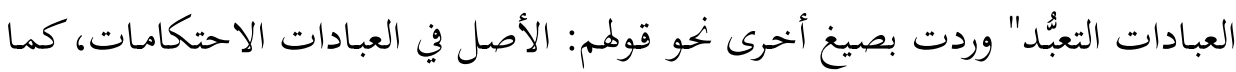

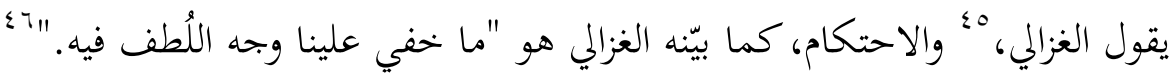

ومن الضمائم كذلك مصطلح التوقيف والتوقُّف، لذلك بند بعض الأصوليين يقول:

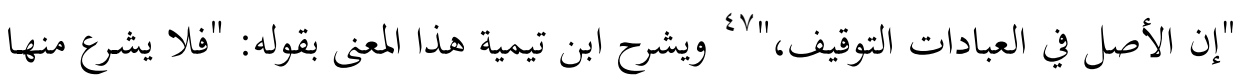

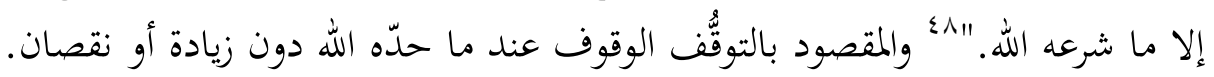
والفرق بين التعبُّد والتوقُف يكمن في أن التعبُّد فعل قصدي يرجع إلى قصد الشارع

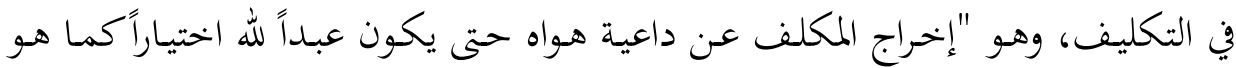
عبد لله اضطرارا." "9 أما التوقُّف فهو عمل وظيفي يقابل التعدية من وجه.

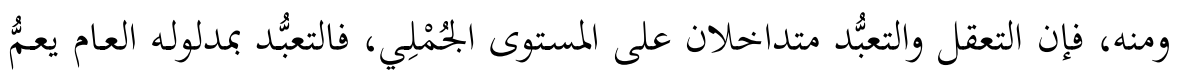

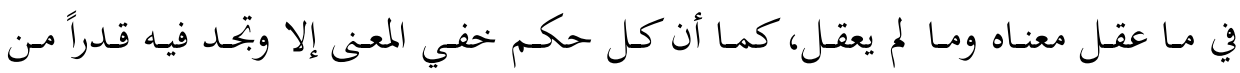
التعقُل.

لذلك، فإن القول بالتعبُّد لا يتعارض في بعض الأحكام مع انتفاء المعقولية، أو أفها

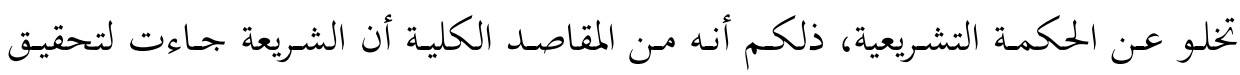

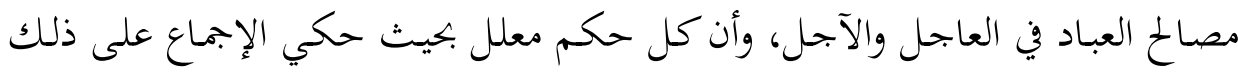

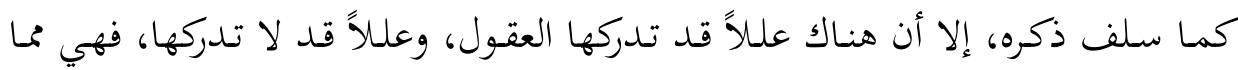

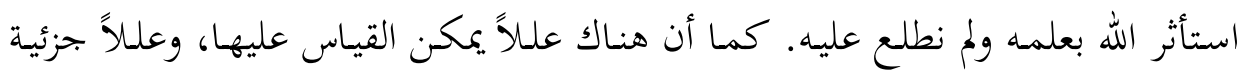
غير منضبطة لا تصلح لأن تكون علة قياسية. م؛ وذلك في:

- الغزالي، أبو حامد. شفاء الغليل في بيان الشبه والمُّخيل ومسالك التعليل، تحقيق: حمد الكبيسي، بغداد:

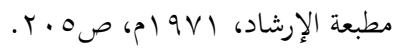

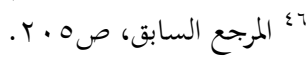

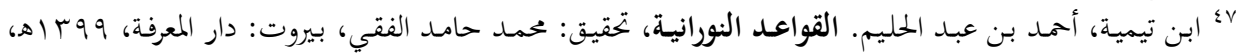

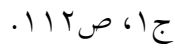

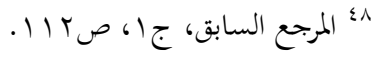

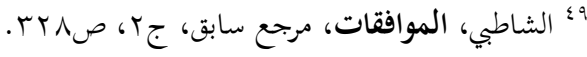




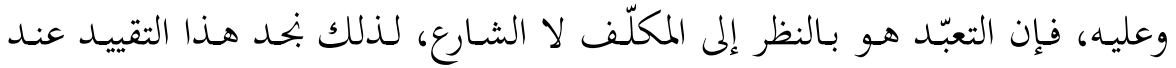

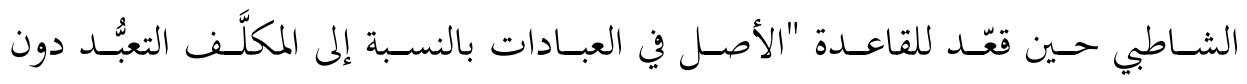

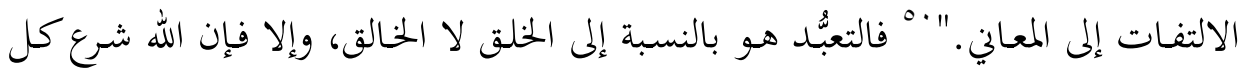
حكم لحكمة تتفاوت الأفهام في إدراكها، ولا يتوقف الامتثال على معرفتها.

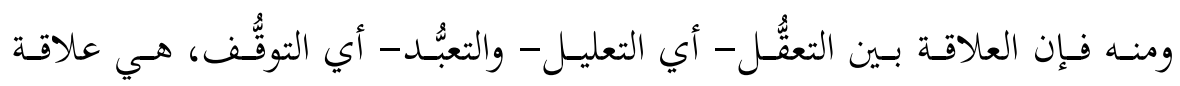

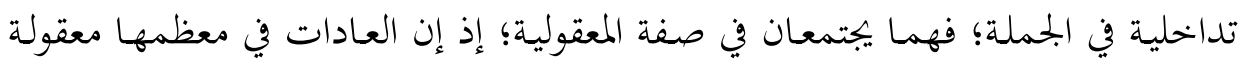

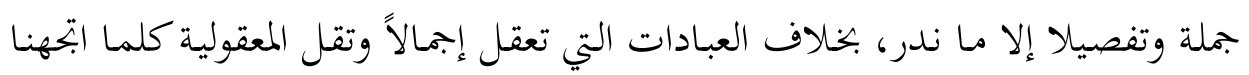

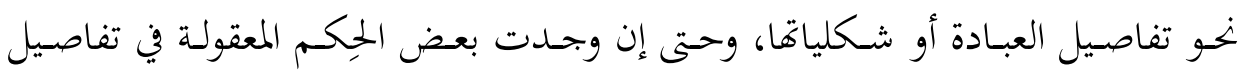

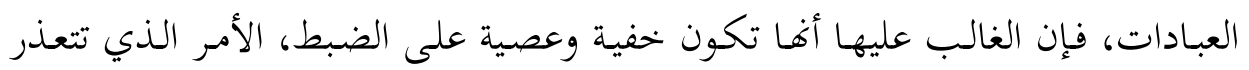

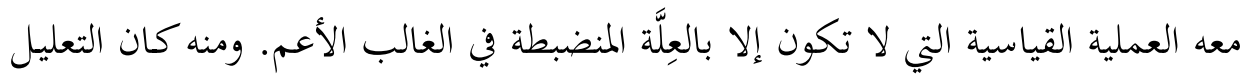

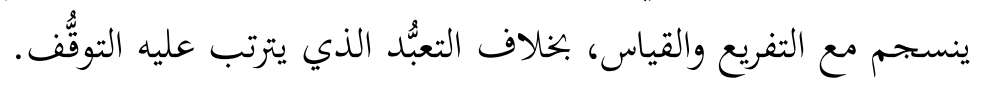

وخلاصة القول إن التعبُّد العام شامل للعبادات والعاديات، أمـا التعبُّد الخاص، أو

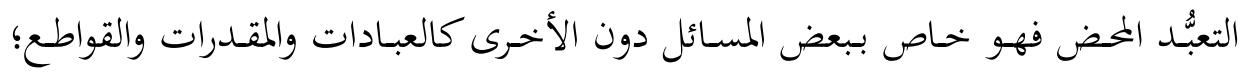

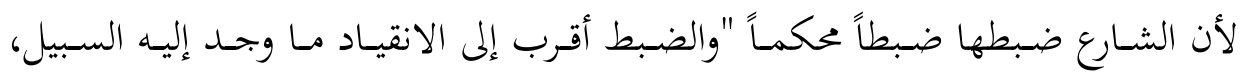

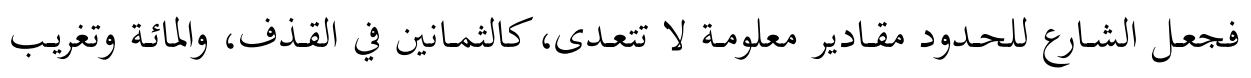

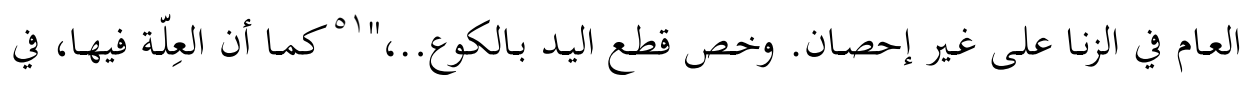

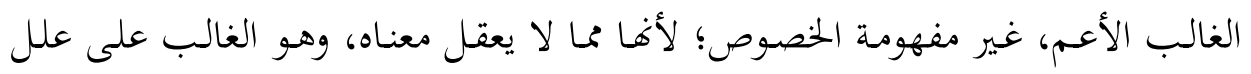

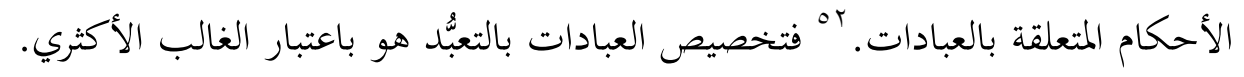

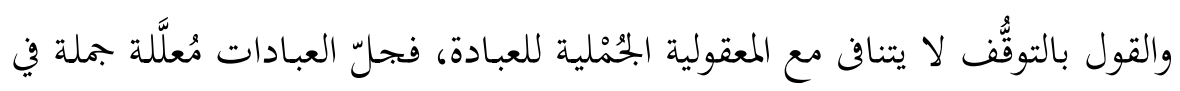

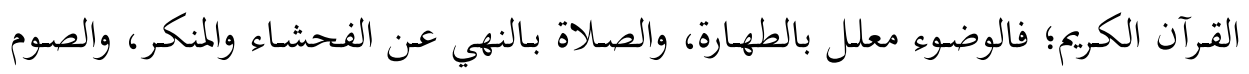

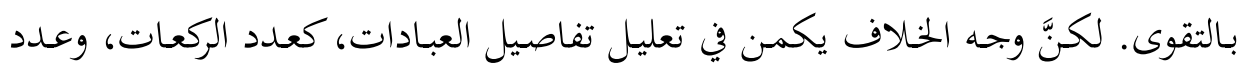

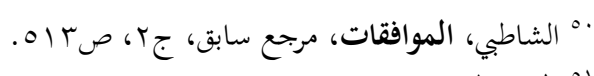

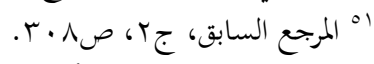
ror الأنصاري، مصطلحات أصولية في كناب الموافقات للشاطبي، مرجع سابق، ص. r ا. 


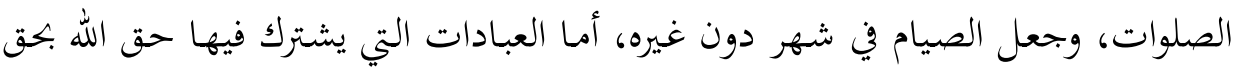

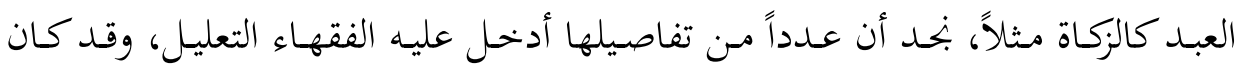

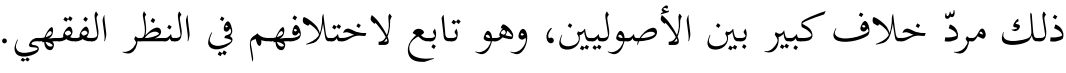

لكن، وإن كان الجمهور ذهب إلى أن الأصل في العبادات التعبُّ، فإن هناك تفصيلاً

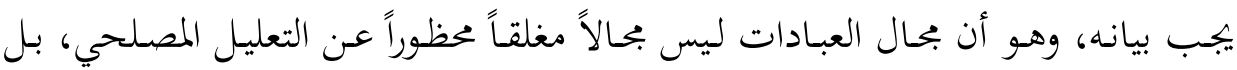

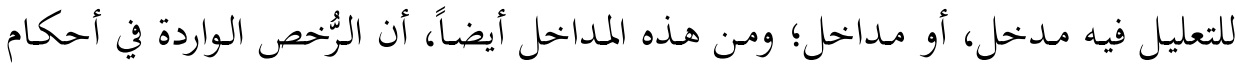

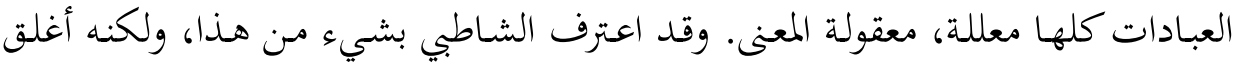
الباب بسرعة؛ إذ قال: "وأيضا فإن المناسب فيها (يعني في العبادات) معدود عندهم فيما

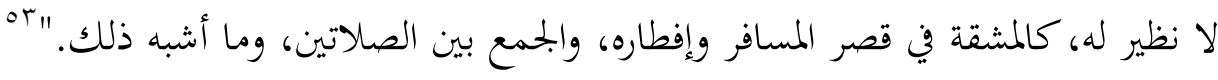
وفي تفاصيل الطهارات وأحكام المياه، لا نستطيع التغاضي، كما يقول الريسوني، عن

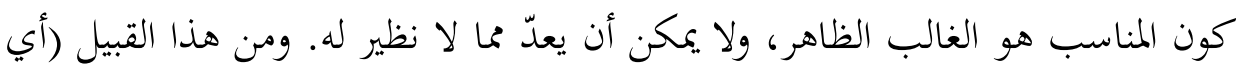

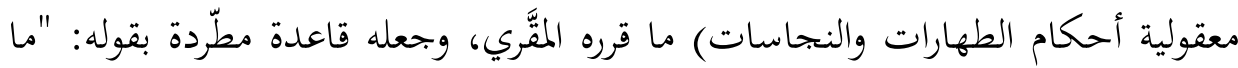

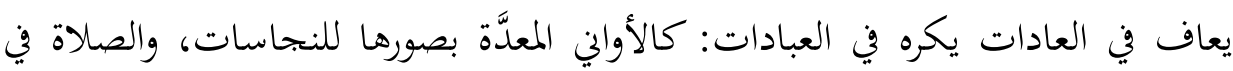

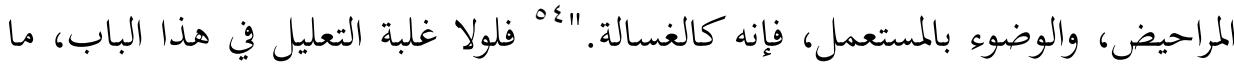

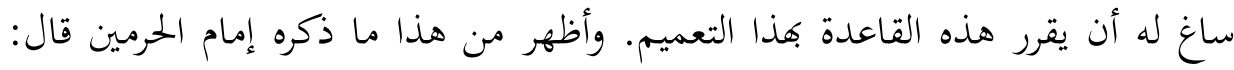

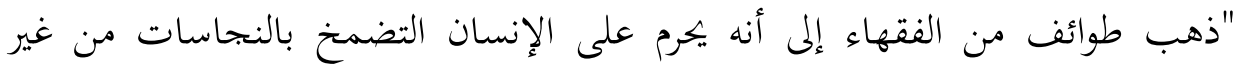
حاجة ماسة وما ذلك إلا لمنافاته للتعليل الوارد عقب ذكر الوضوء والاغتسال في الآية:

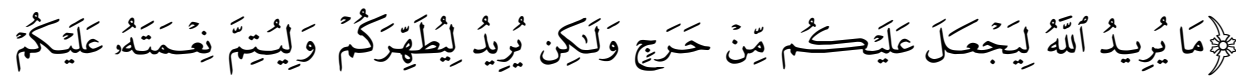

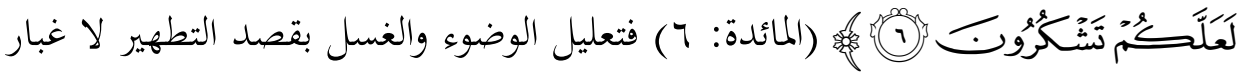
عليه، وإن لم يكن المقصود الوحيد.

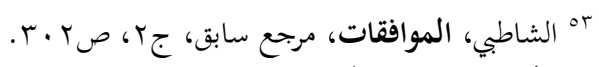

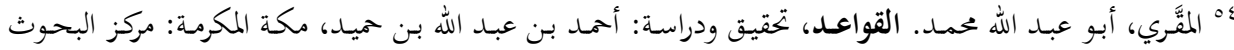

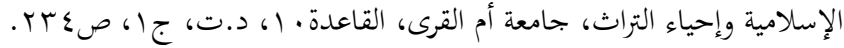

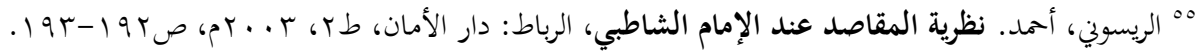




\section{ثانياً: محددات التفريق بين العادات والعبادات}

بعد أن تبيّنّا بعض محلددات مفهوم العبـادة ارتأينـا تمييزه عما يقابله في الاستعمال

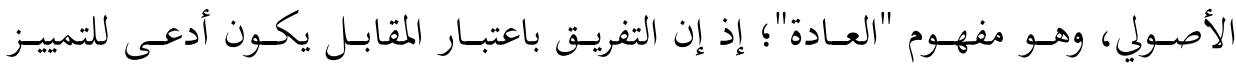
والتحديد.

\section{I التفريق باعتبار محددات المفهوم:}

راجـت في التواليف الأصولية أن الأصل في العبادات التعبُّد، وفي العادات الالتفـات إلى المعاني، لكن وجدنا بعض العادات كان الأصل فيها الوقوف عند ما حدَّ الشارع دون تحديد، مما يحتم بتحلية ضوابط التفرقة والتمييز بين العادي والعِبَادي.

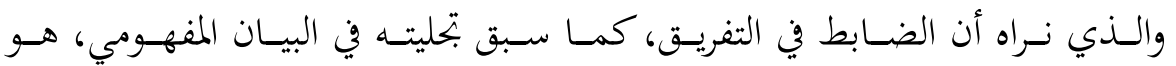

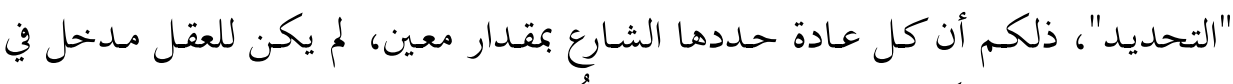

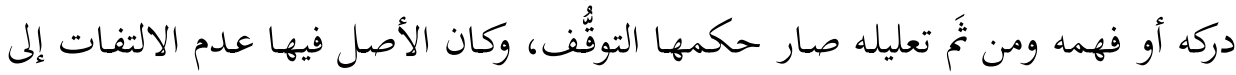

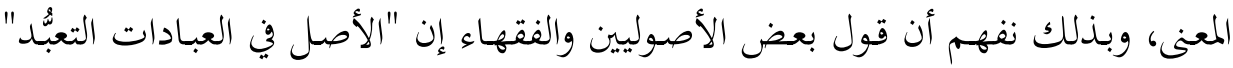

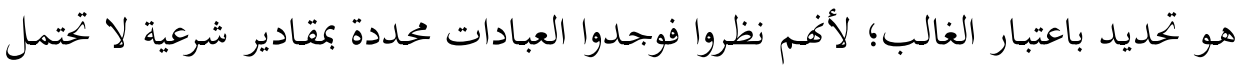

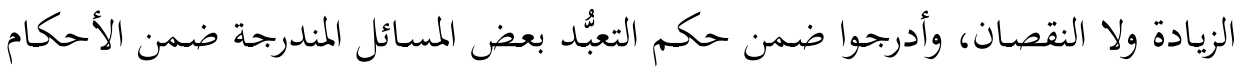

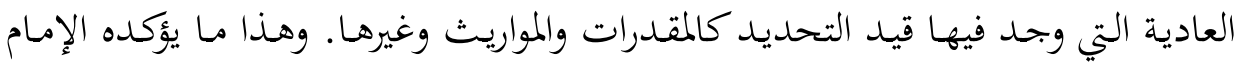

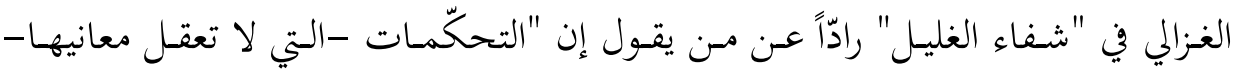

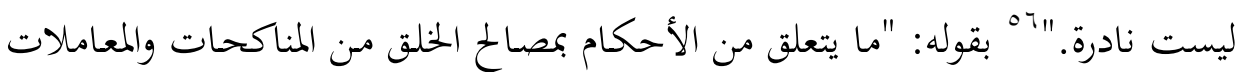

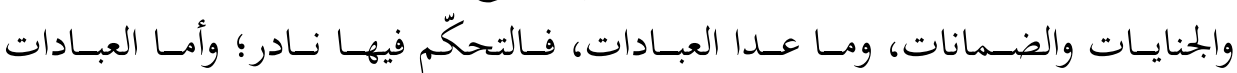

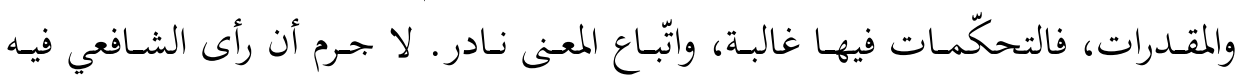

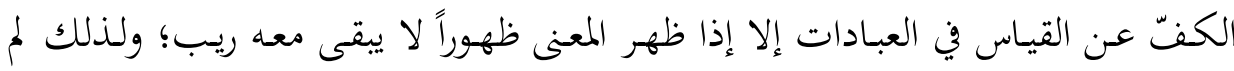

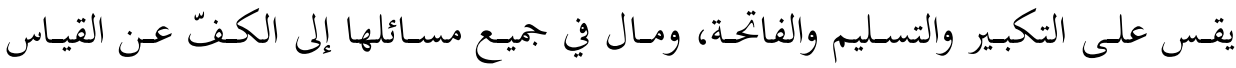

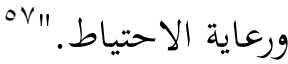

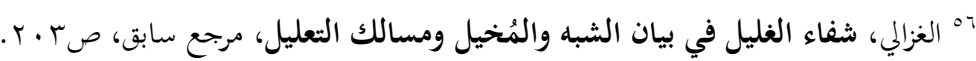

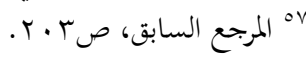




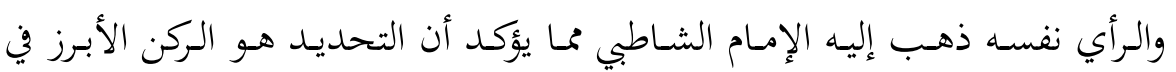

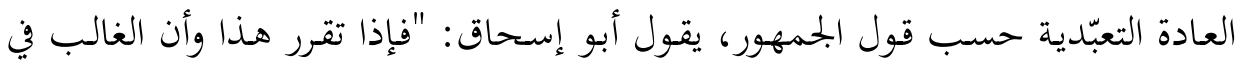

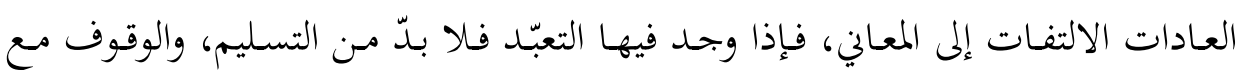

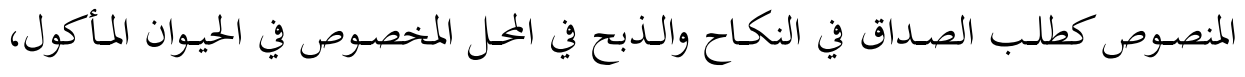

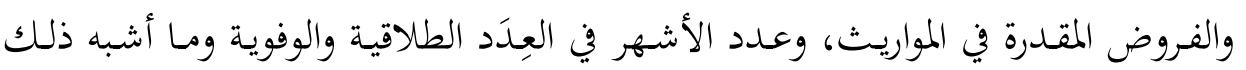
من الأمور التي لا بحال للعقول في فهم مصالحها الجزئية حتى يقاس عليها غيرها، فئد فإنا

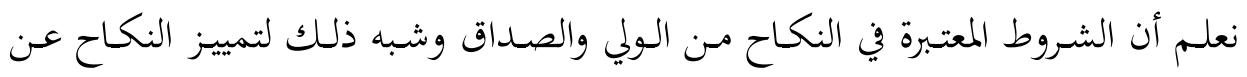

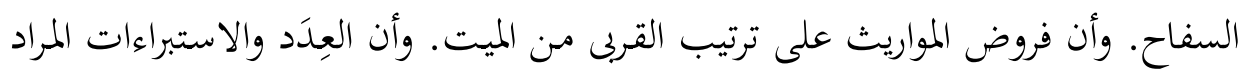

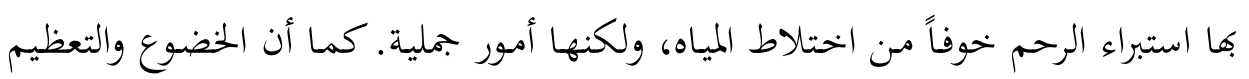

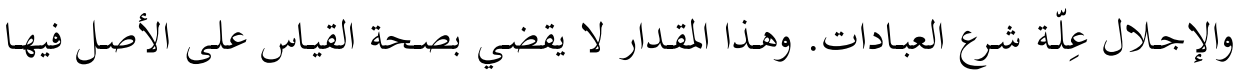

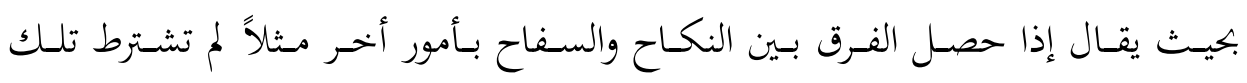

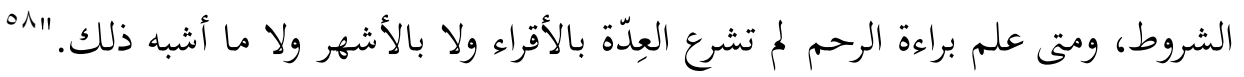

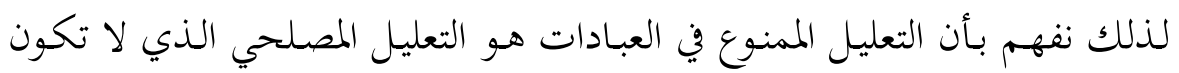

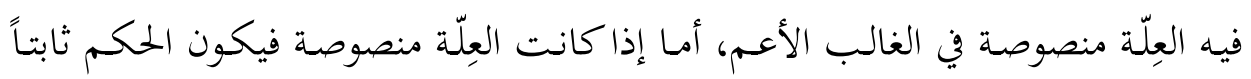

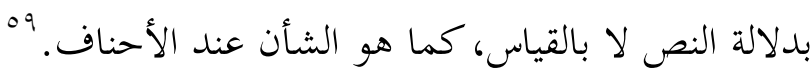

لذلك بحد الأئمة النظّار مازوا هذا المعنى ببيان أن التفاصيل المقدرة، التي لا بحال

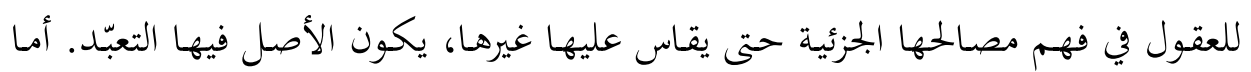

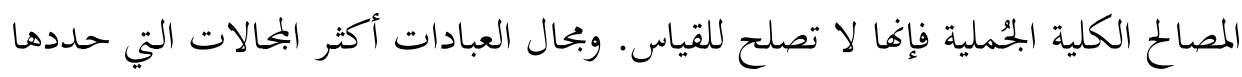

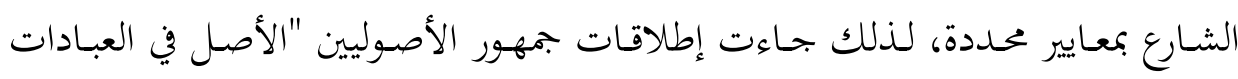

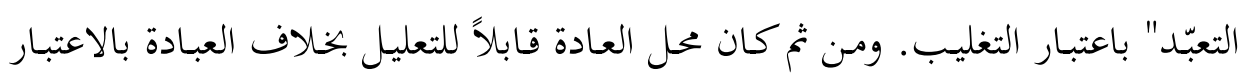

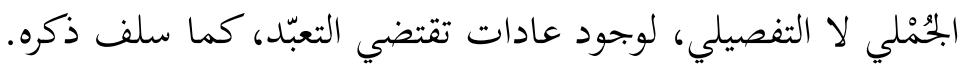

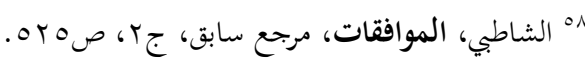

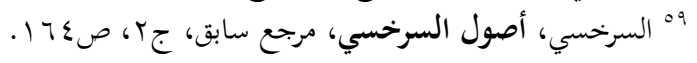




\section{Y r. التفريق باعتبار علاقة الشرط مع المشروط:}

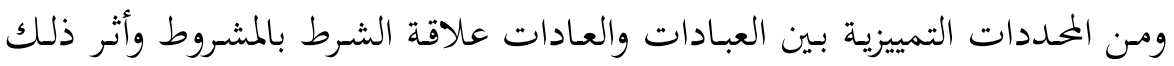

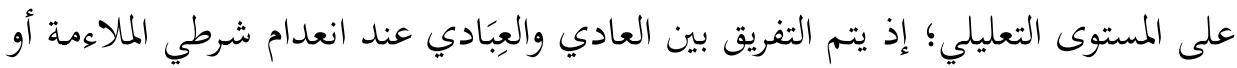

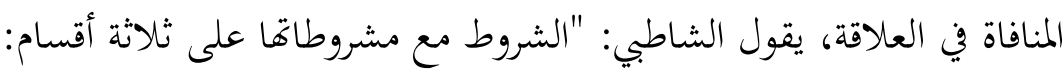
أحدها: أن يكون مكملاً لحكمة المشروط وعاضداً لها بحيث لا يكون فيه منافاة لها على حال،

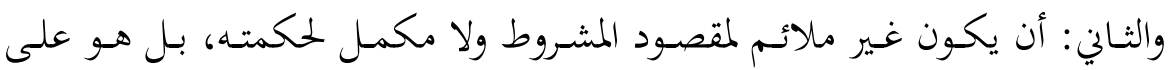

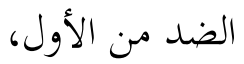

والثالث: أن لا يظهر في الشرط منافاة لمشروطه ولا ملاءمة. وهو محل نظر : هل

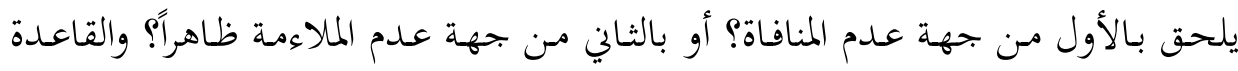

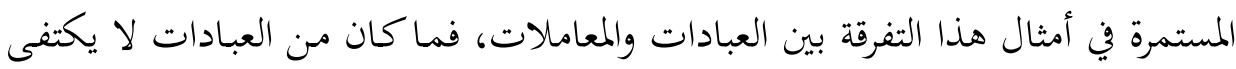

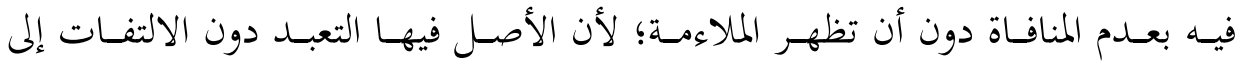

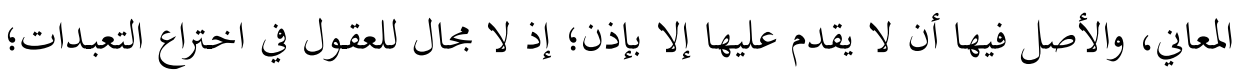

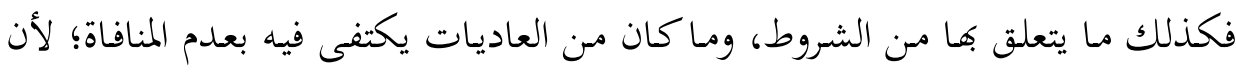

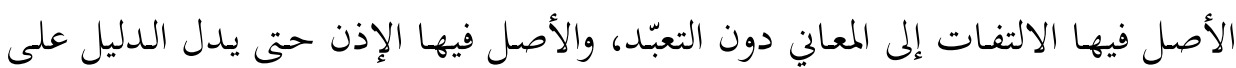
خلافه." (")

وهذا ما فصّله الغزالي قبله أيضاً بالنظر إلى أقسام الأحكام، يقول: "الأحكام ثلاثة

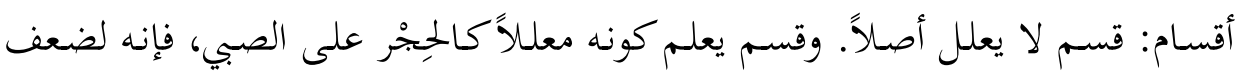

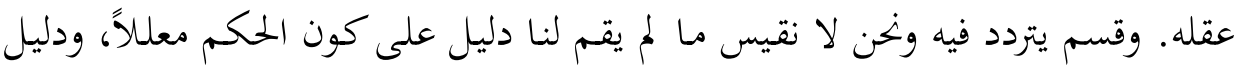

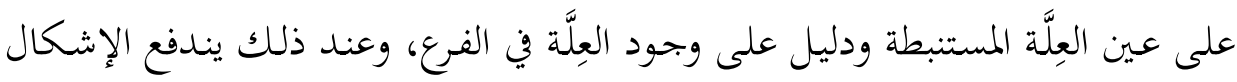

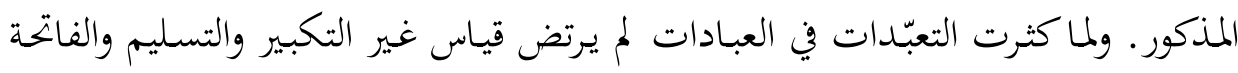


عليها، ولا قياس غير المنصوص في الزكاة على المنصوص، وإنما نقيس في المعاملات،

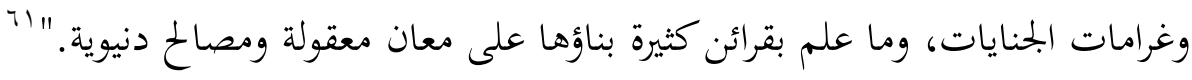

ومنه فإن الجوانـب المعَلّلة في العبـادة تقتضي وجـود شرطين؛ الشـرط الأول: عـدم

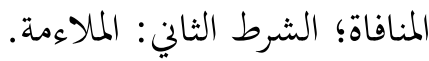

وبيان ذلك كما سبق أن الأصل في العبادة التوقّف؛ أي إنه لا يقدم عليها إلا بإذن

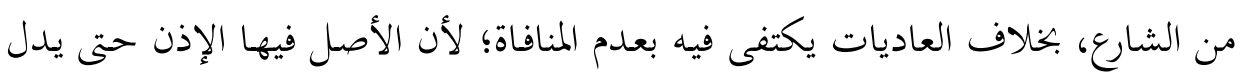
الدليل على خلافه.

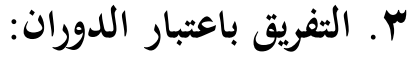

سلف معنا أن العِلل في العبادات لا تدلّ على معنى ظاهر منضبط مناسب يصلح

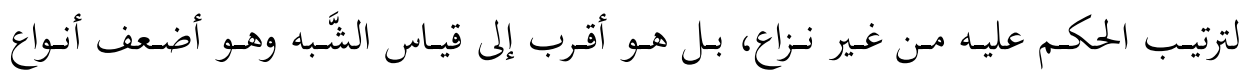

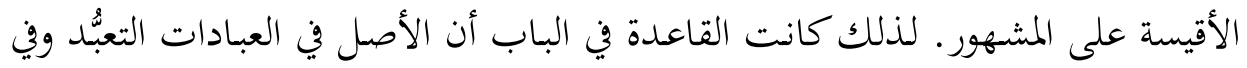

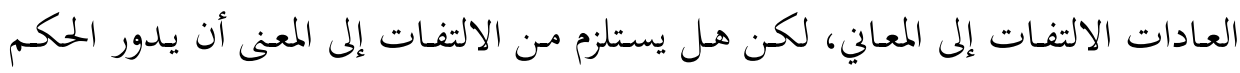

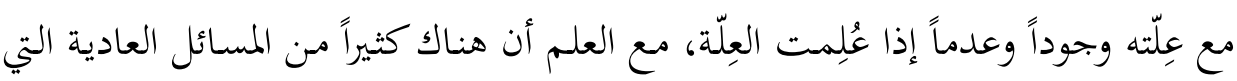

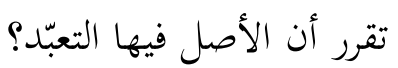

والجمواب على ذلك يتمثل في أن إناطة الأحكام العادية بالعلل لا يستلزم دوراهـا

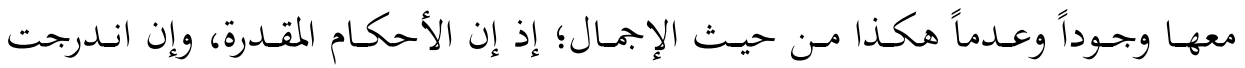

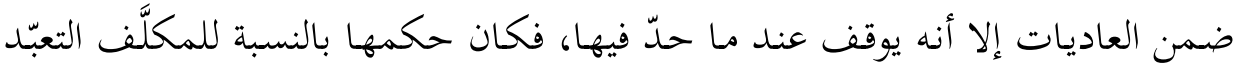

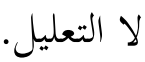

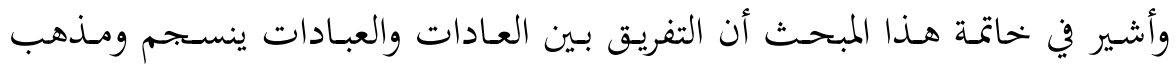

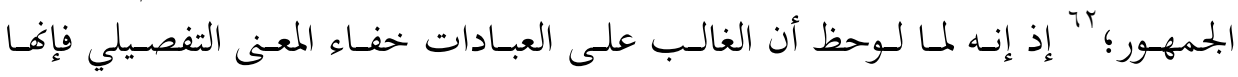
"" الغزالي، المستصفى في علم الأصول، تعقيق: عمد عبد السلام عبد الشافي، بيروت: دار الكتب العلمية، طا،

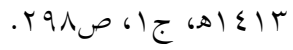
"ir يقول المقري في قواعد الفقه إن عدم تعليل أحكام العبادات أصل من أصول الإمام الشافعي. انظر: 
شَّلت بذلك منطقة اللامُعلّل في النسق الأصولي، عكس العادات التي غلب عليها بيان

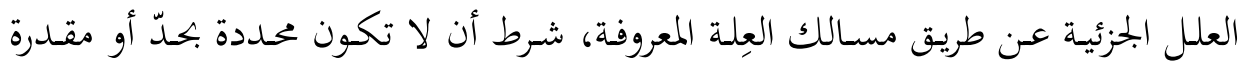

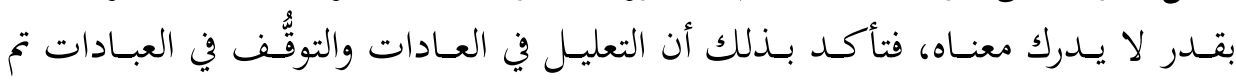
باعتبار النظر الأغلبي الأكثري.

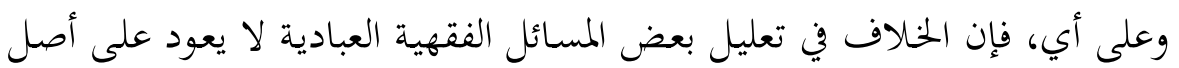

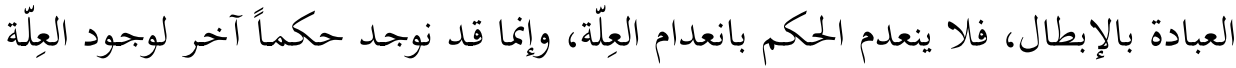
نفسها في المحل الآخر.

وهذا يخالف تلكم الاجتهادات غير المنضبطة نحو القول مثلاً: إن القصد مـ عددة

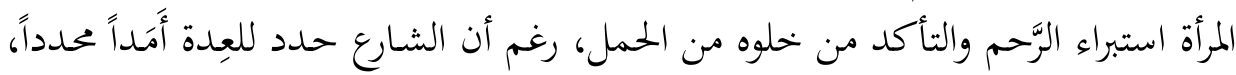

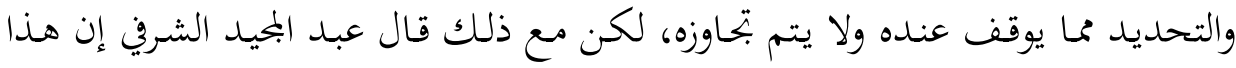

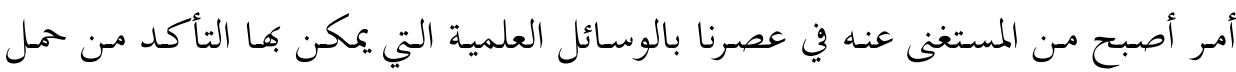

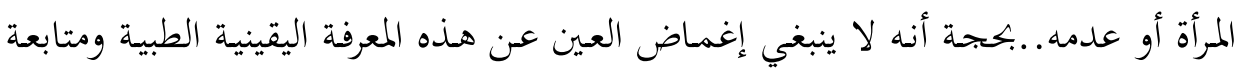

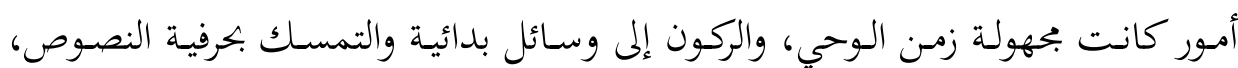

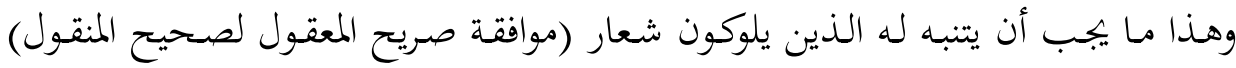

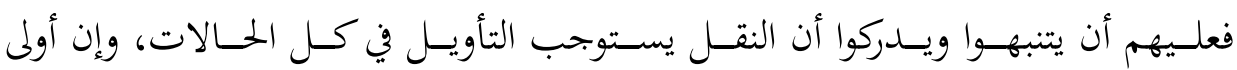

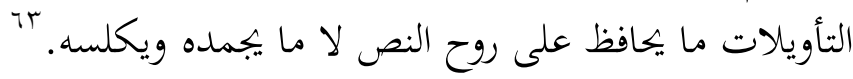

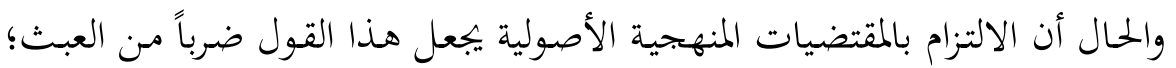

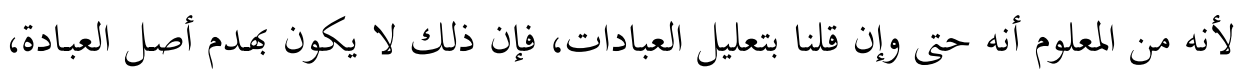

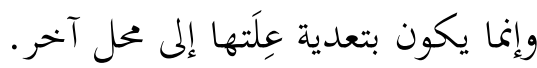

\section{ثالثاً: أدلة الجمهور على التوقُّف في العبادات}

يُعد الشاطبي أبرز من عرض للمسألة ذاكراً مستنداها وأدلتها، لذلك سيتم الاكتفاء

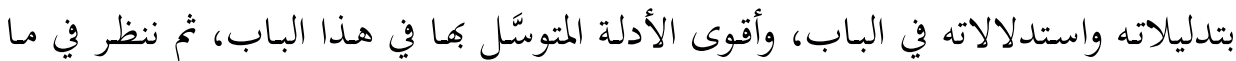
يعارضها من الأدلة.

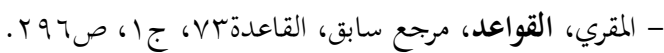

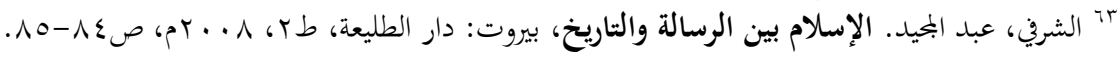




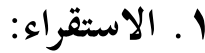

بنى أبو إسحاق هذا القول عند النظر في جملة مسائل تندرج ضمن العبادات وتعذر فيها التعليل والتعدية، يقول: "فإنا وجدنا الطهارة تتعدى محل موجبها، وكذلك الصلوات

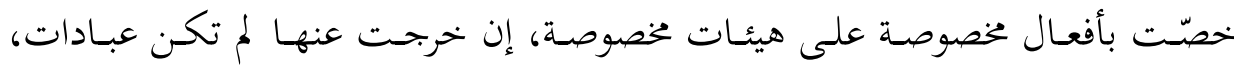
ووجددنا الموجَبَات فيها تتحد مع اختلاف الموجَبَات، وأن الذّكر المخصوص في هيئة مـا مطلـوب، وي هيئسة أخــى غـير مطلـوب... وهكـذا سـائر العبـادات؛ كالصـوم والحـج، وغيرهما؛ وإنما فهمنا من حكمة التعبّد العامة الانقياد لأوامر الله تعالى، وإفراده بالخضوع، هيته والتعظيم لجلاله والتوجه إليه، وهذا المقدار لا يعطي عِلة خحاصة يُفهم منها حكم خاص؛

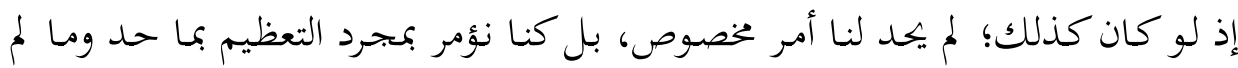
يجد، ولكان المخالف لما حُدَّ غير ملوم إذا كان التعظيم بفعل العبد المطابق لنيته حاصلاً، وليس كذلك باتفـاق، فعلمنـا قطعـاً أن المقصود الشرعي الأول التعبّد لله بـذلك المحدود،

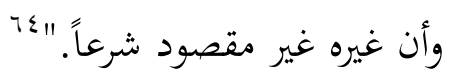

فوجْـهُ الشـاهد مـن الأمثلـة السـابقة أن العِلـل المناطـة بالعبـادات لا يقـاس عليهـا ولا تتعدى إلى غير محالها لخفاء العلة الخاصة التي يراد منها الحكم الخاص. وخحلاصـة القـول في تــليل أبي إسـحاق أنـه توسـل بالاستقراء في هـــا البـاب لرفـع

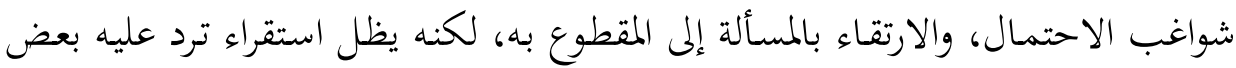

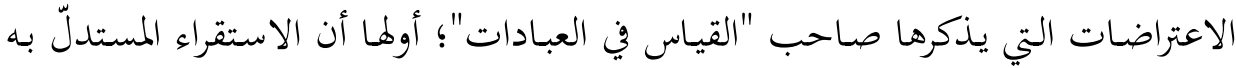

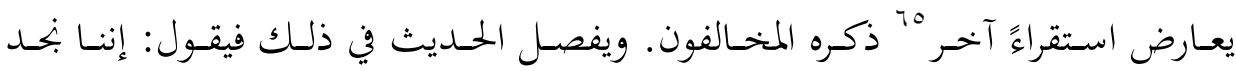

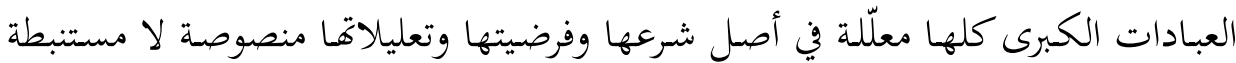

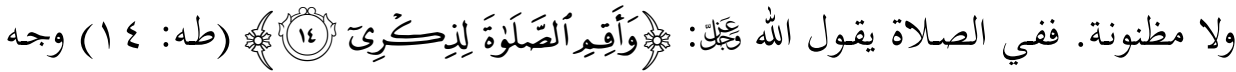

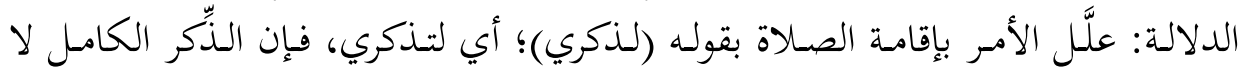




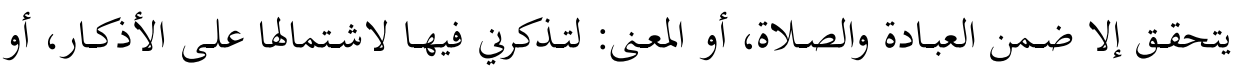
المعنى: أقم الصلاة عند ذكرك لي، أو لأذكرك بالمدح وعليين هما.

ويعارض هذا الككام أيضاً بأن محل النزاع ليس التعليل الجهُملي، فالشاطبي نفسه الذي استدل بالاستقراء في هذا الموضع، أقرّ في موضع آخر بالقول: "أما التعاليل

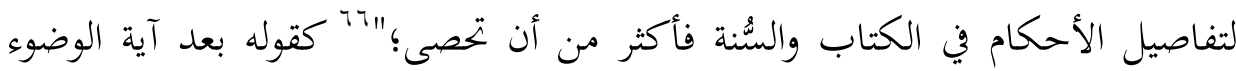

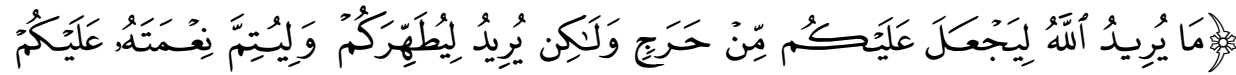

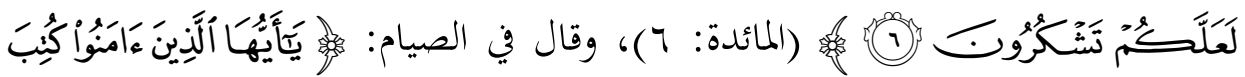

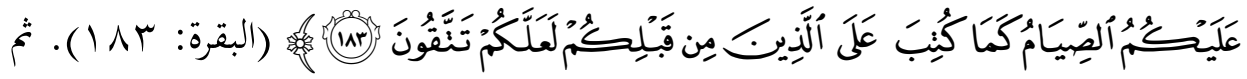
يقول: "وإذا دلّ الاستقراء على هذا، وكان في مثل هذه القضية مفيداً للعلم؛ فنحن

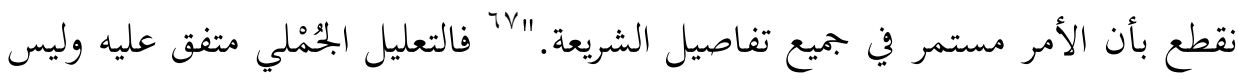
محل النزاع، بخلاف تعليل تفاصيل العبادات، لكن وجه الإشكال الحقيقي في تدليل أبي إسحاق هو بتمثيله بتفريعات هي محل خلاف.

\section{Y. نهي بعض الصحابة عن القياس على بعض العبادات:}

من الأدلة التي يستدل بها على عدم تعليل العبادات، فهي عائشة رضي الله عنها لما

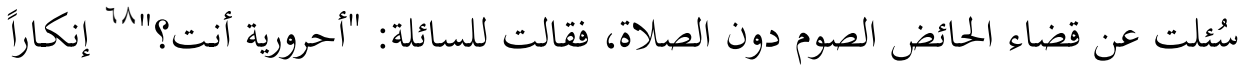
عليها أن يسأل عن مثل هذا؛ إذ لم يكن من شأن التعبُّدات أن تفهم عِلتها الجزئية، ثم

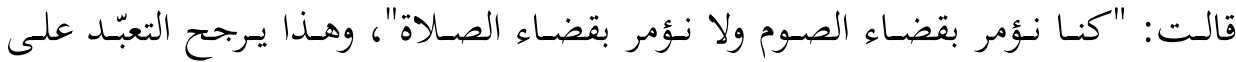
التعليل بالمشقة، وقول ابن المسيب في مسألة تسوية الشارع بين دية الأصابع: "هي السُّنة با ابن أخي"، وهو كثير، ومعنى هذا التعليل أن لا عِلّة. 79

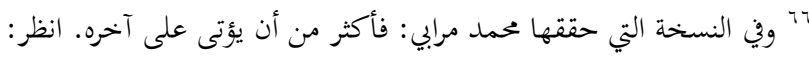

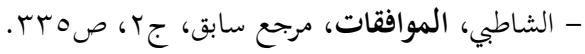

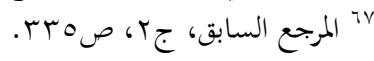

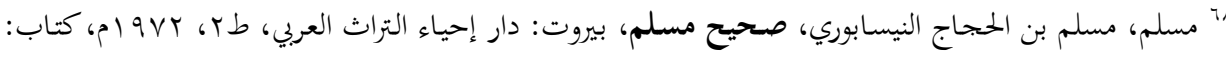

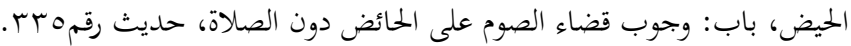

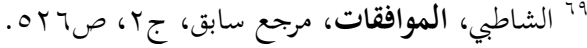


لكن نفي التعليل المراد في هـا السياق هو التعليل القياسي الذي يروم التعدية لا

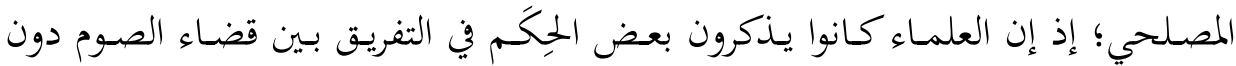

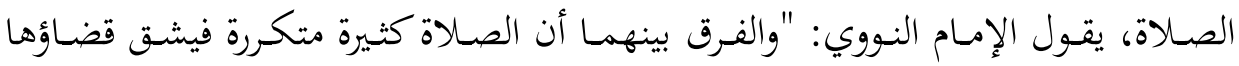

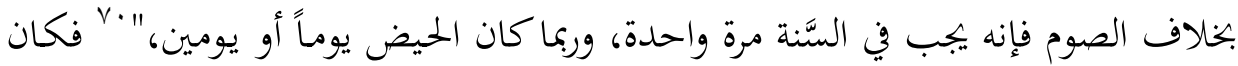
عدم القضاء من رحمة الله بإمائه وتيسره عليهن وإحسانه وفضله.

ويُرَدُّ على هـذا الدليل بأنه لا يـدل على منع التعليل في العبادات؛ لأن أم المؤمنين

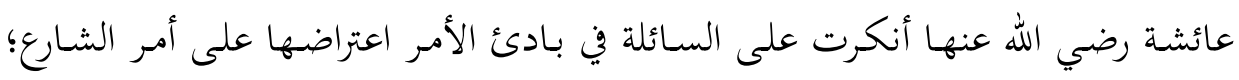
لأن مثل هذا السؤال ممنوع.

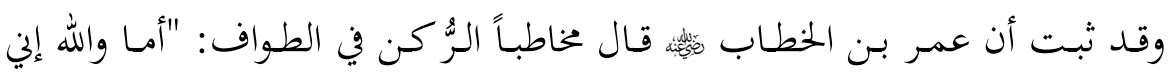

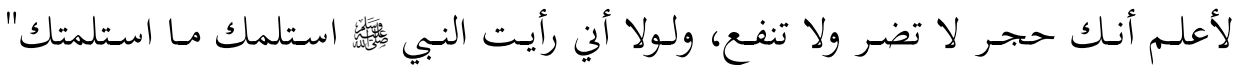

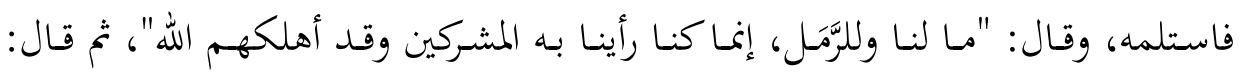

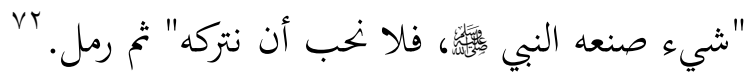
فهذا مثال للعبادات التي زالت عِلة تشريعها، ولم يعدم الحلكم لانعدام العِلة، فرغم

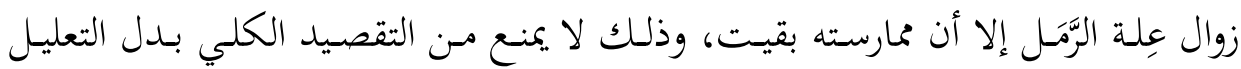
الجزئي الذي يدور معه الحكم وجوداً وعدماً.

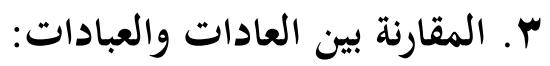
وهـو استـلال بالضِّد، فبضـدها تتمـايز الأشياء كمـا يقـال، وانطلاقاً مـن نصـوص القرآن والسنة فقد تبين أن الشارع "نصب على التوسعة في وجوه العادات أدلة لا يوقف لهف

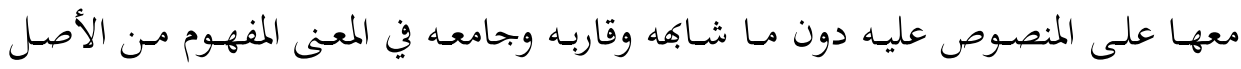

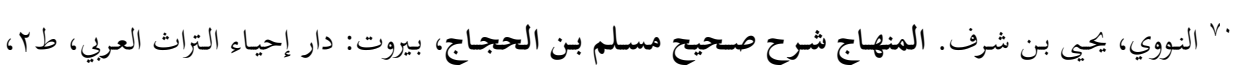

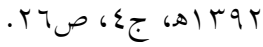

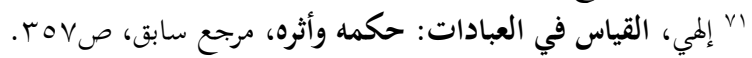

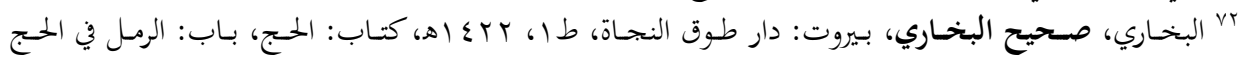

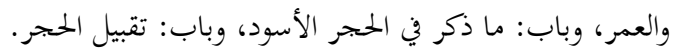


المنصوص عليه، ولكان ذلك يتسع في أبواب العبادات. ولما لم بند ذلك كذلك، بل على خلافه؛ دل على أن المقصود الوقوف عند ذلك المحدود؛ إلا أن يتبين بنص أو إبماع معنى مراد في بعض الصور، فلا لوم على من اتبعه، لكن ذلك قليل، فليس بأصل؛ وإنما الأصل

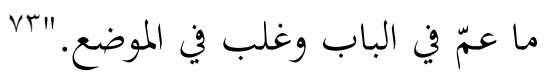

وقول الشاطبي الأخسير يؤكد وجـود بعض الصـور التي ثبـت فيها الالتفـات للمعنى،

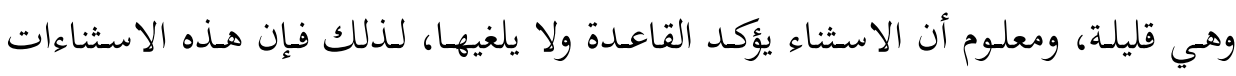
تؤكد أصل التعبّد في العبادات؛ لأن الأصل ما عمّ في الباب، كما قال أبو إسحاق. وقد تكون هذه الصور هي تلكم المختلف فيها بين الجمهور والأحناف في تعليل العبادات.

وانطلاقاً من هذا التدليل الأخير يتأكد لنا الفرق الجوهري بين مـا هو عادي وما هو عِبادي في الدرس الأصولي؛ ع فالعبادات تتميز بالتحديد مع غياب النص على التعدية

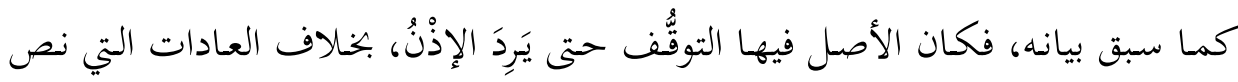
الشارع بأدلة جُمْلية وتفصيلية على جواز التعدية. ومنه فإننا نتقرب إلى الله في بحال العبادات بما حدّ وإن وجد غيره؛ لأن الانقياد هو الأصل فيها من غير زيادة ولا نقصان، كما أن المقصود الشرعي يقع في التحديد أيضاً. خصوصاً أن أكثر العلل المفهومة الجنس في في أبواب العبادات غير نفير مفهومة الخصوص، كما سلف ذكره.

\section{ع. التحسين والتقبيح العقليان:}

وقد ذكر هذا الدليل أبو إسحاق الشاطبي، وفيه نزاع مشهور، كما قال ابن تيمية،

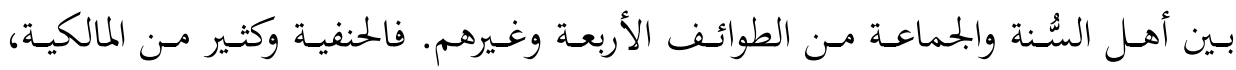

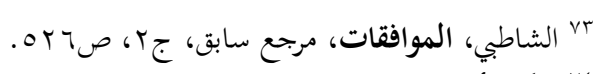

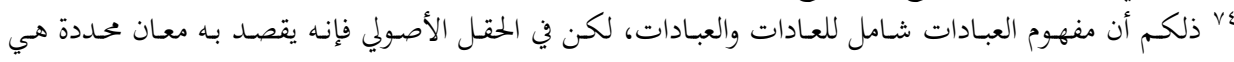


والشافعية والحنبلية، يقولون بتحسين العقل وتقبيحه، وهو قول الكرامية والمعتزلة، وهو

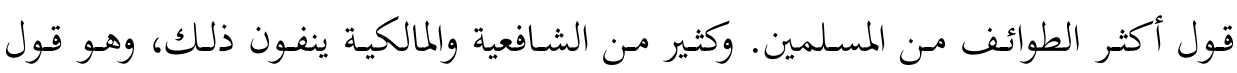

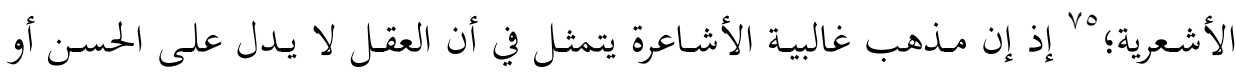

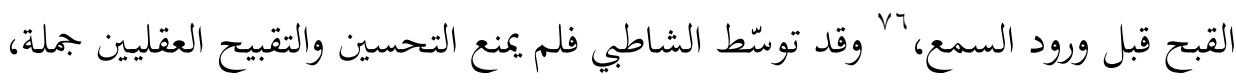

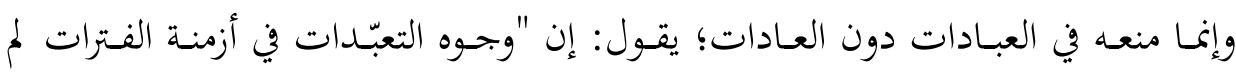

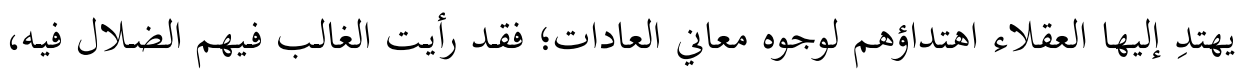

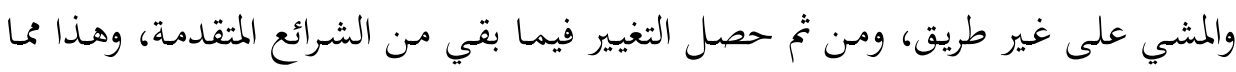

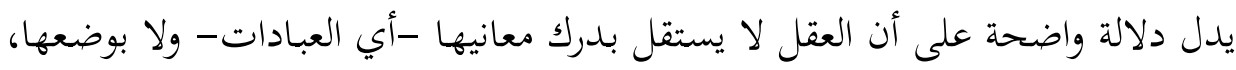

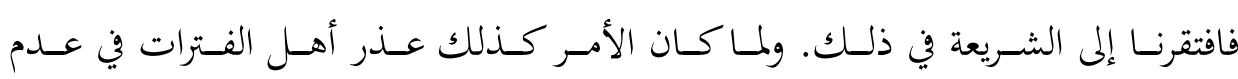
اهتدائهم.

\section{رابعاً: تقصيد العبادات}

والمقصود بالتقصيد في هذا الباب البحث عن مقاصد العبادات الكلية أصالةً والجزئية تبعاً، وذلك بغية الارتقاء بالتديّن ونشر الوعي المقاصدي على مستوى الأمة قبل النخبة. والباحث في الأدبيات الأصولية يجد عـدداً مـن العلمـاء عبّروا بمصطلح مقاصد أو

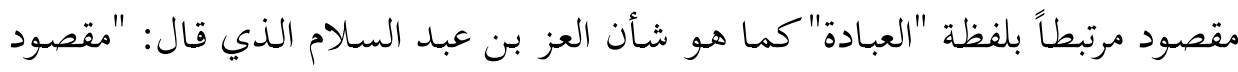

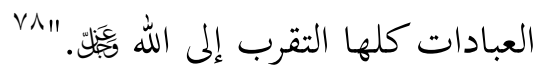

º ابن تيمية، أمد بن عبد الحليم. مجموعة الفتاوى، عناية وتخريج: عامر الجزار، وأنور الباز، المنصورة: دار الوفاء،

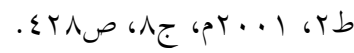

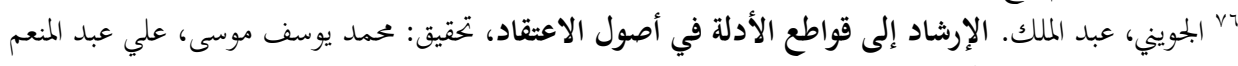

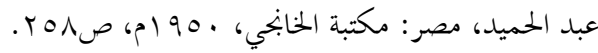

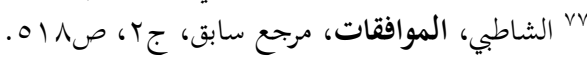

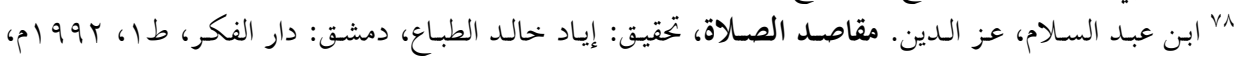


ونشير هنا إلى أن معنى المقاصد في هذا المساق أقرب إلى معنى الأسرار لهو الذي يفيد

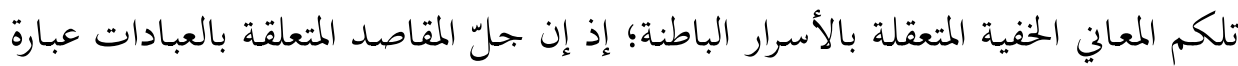

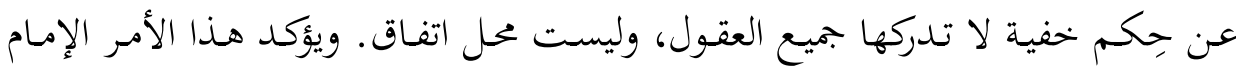
الدهلوي، الذي يقول: "كيف ولا تتبين أسراره إلا لمن تمكّن في العلوم الشرعية بأسرها،

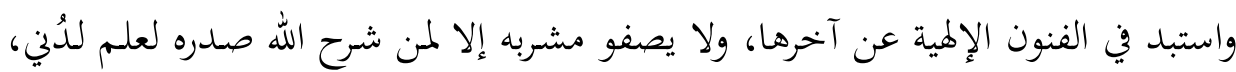

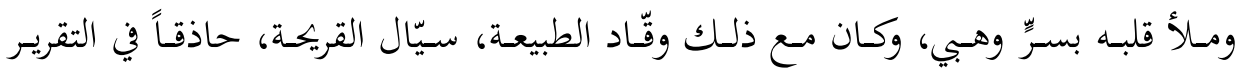

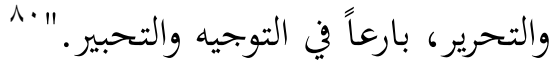

ومن ثم، كان تقصيد العبادات ضرباً من البحث عن أسرار الحكم التي بثها الله عزّ

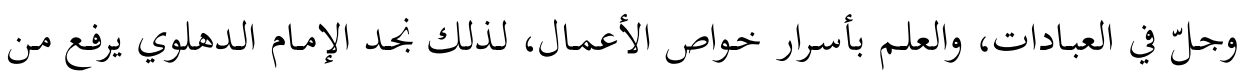

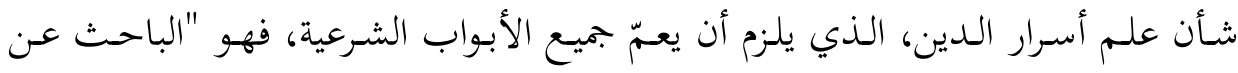

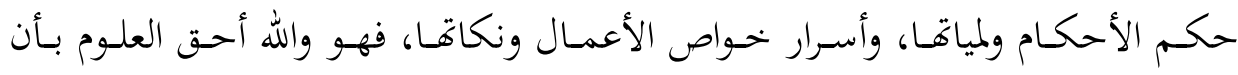

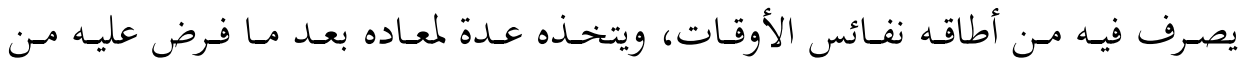

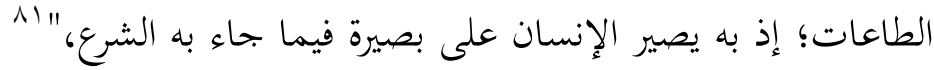
ولما كان الغرض من هذه الدراسة هو مقاربة إشكالية تعليل العبادات أصولياً، وجبب

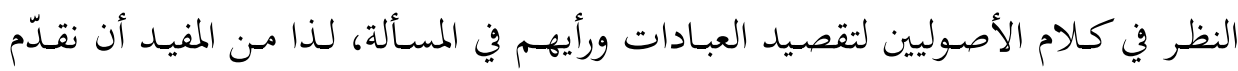

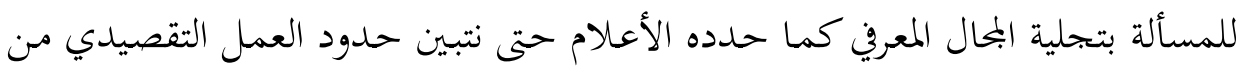
الوجهة الأصولية.

\section{1 ا ـ دراسة في المجال المعرفي:}

والمقصود بذلك تحديد بحال تقصيد العبادات بالنظر إلى تعليلها، ذلكم أن الناظر في

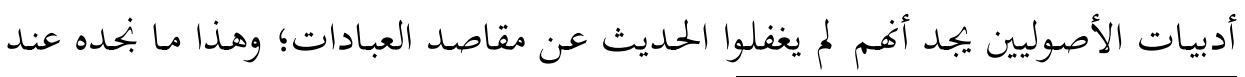

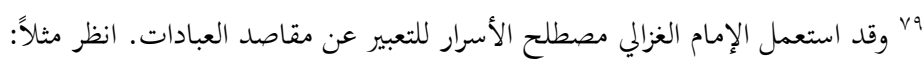

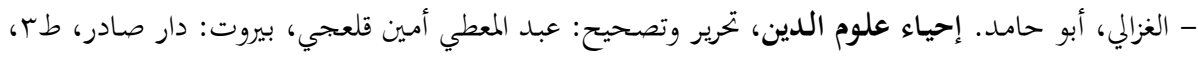

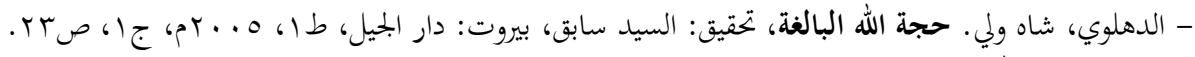

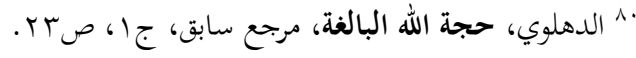

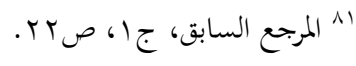




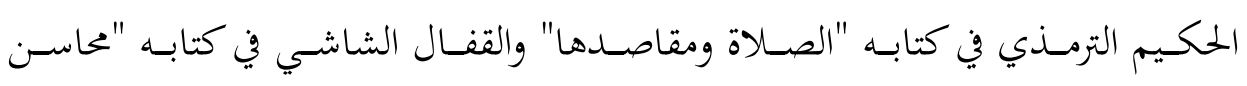

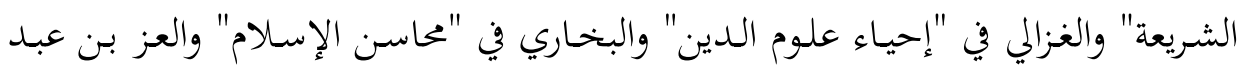
السلام في كتابه "مقاصد الصوم" وغيرهم كثير.

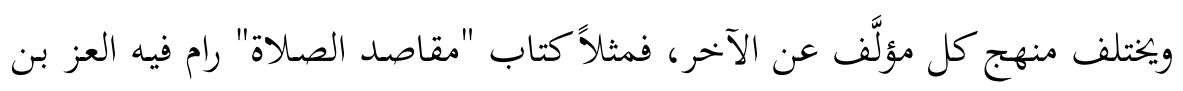

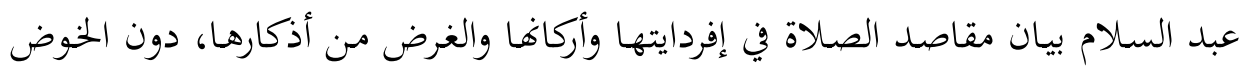

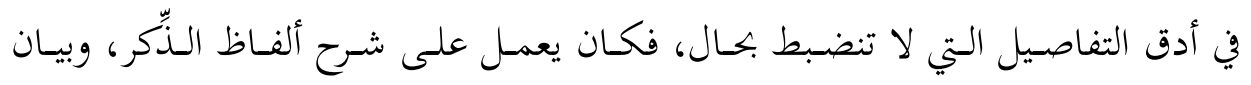

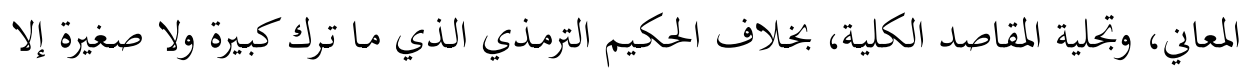
علّلها.

والملاحظ على هذه التقصيدات الجزئية أها لا تنضبط بضابط علمي؛ إذ إهـا تظل

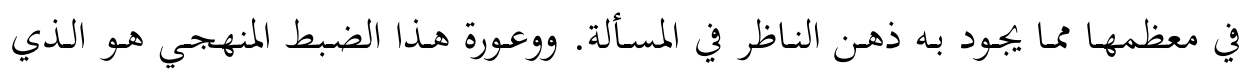

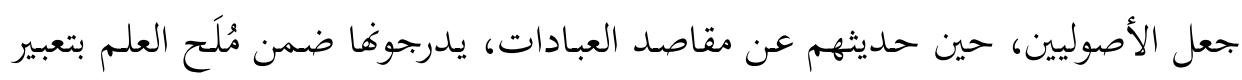

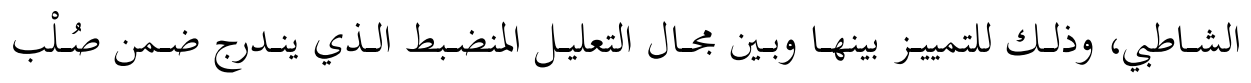

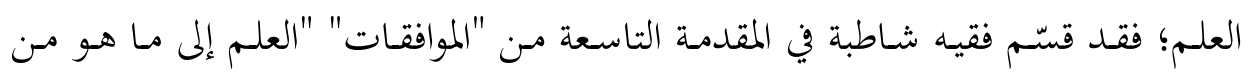

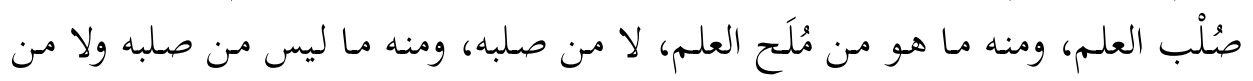
ملحه، فهذه ثلاثة أقسام: مأبه

القسم الأول: هو الأصل والمعتمد، والذي عليه مدار الطلب، وإليه تنتهي مقاصد

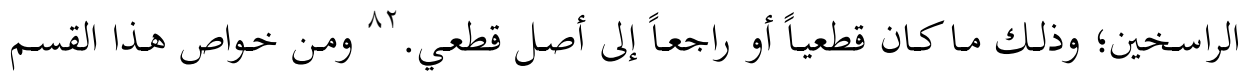

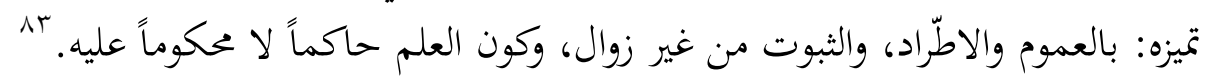

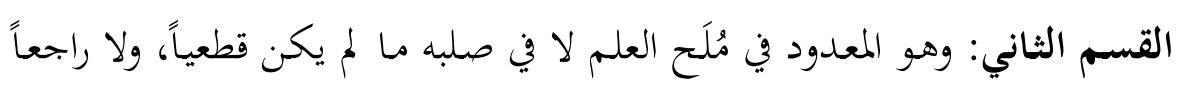

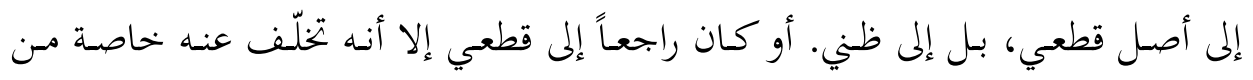

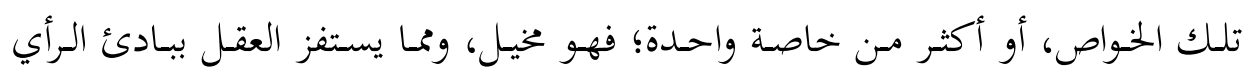

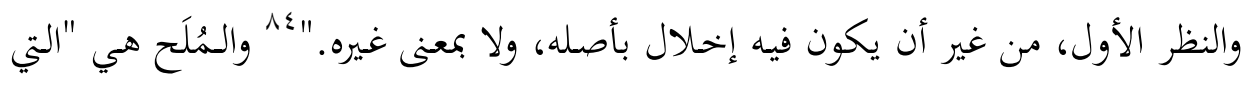

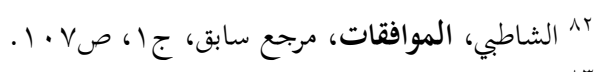

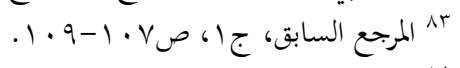

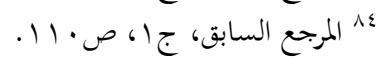


تستحسنها العقـول، وتستملحها النفوس؛ إذ ليس يصسحبها منفِّر، ولا هي ممـا تعـادي

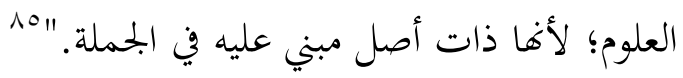

وعليه، فإن تخلّف إحدى الخواص المميزة لصلب العلم جعل تقصيد العبادات يلتحق

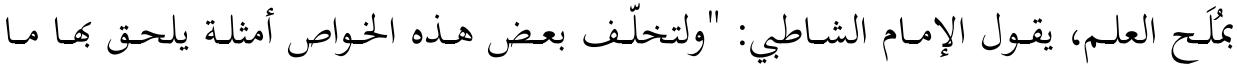
سواها:

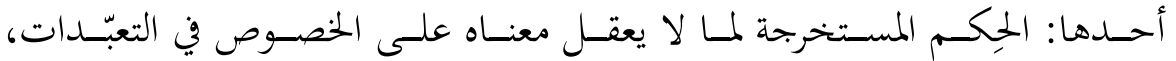
كاختصاص الوضوء بالأعضاء المخصوصة، والصالاة بتلك الهيئة مـ رفع اليدين والقيام والركوع والسجود، وكوها على بعض الهيئات دون بعض، واختصاص الصيام بالنهار دون

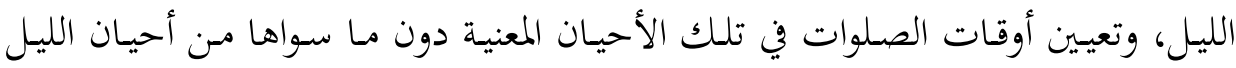

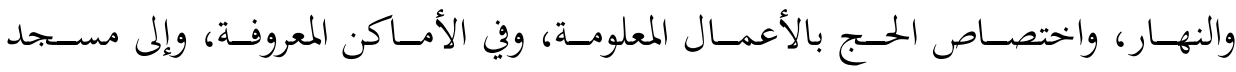

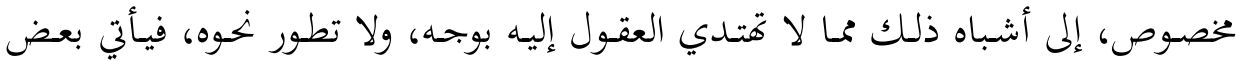

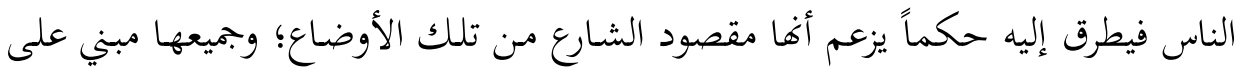

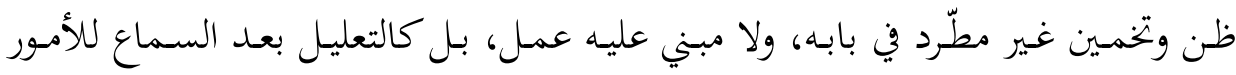

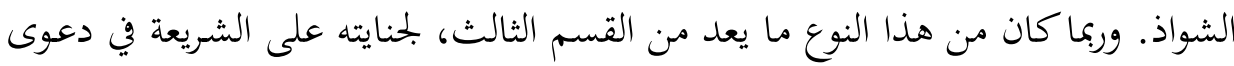

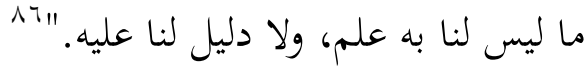

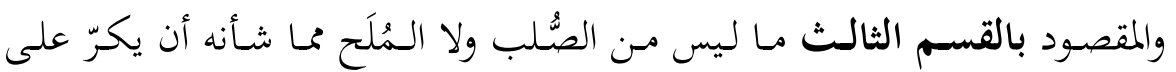

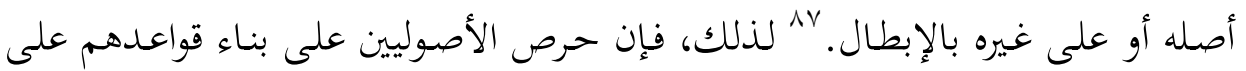

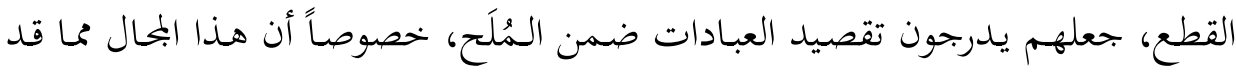

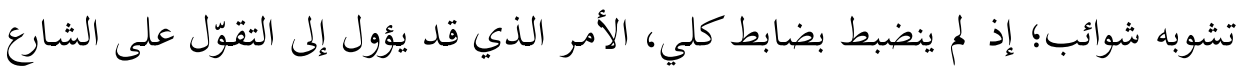
فيما لمُ يَقُلْه، ونسبة ذلك إلى الشريعة والادعاء فيها بغير علم أو برهان.

وعليه، يظهر لنا أن الخلاف بين التعليل والتقصيد يتجلى على المستوى المحالي أكثر؛ إذ إن تعدية الحِكِم تندرج ضـمن صُلْب العلم، بتعبير الشاطبي؛ لأن الغرض مـن التعليل 


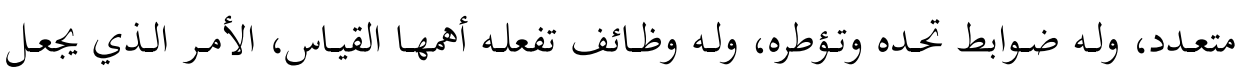

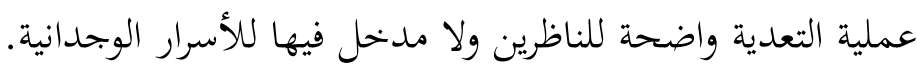

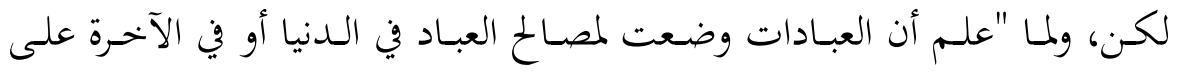

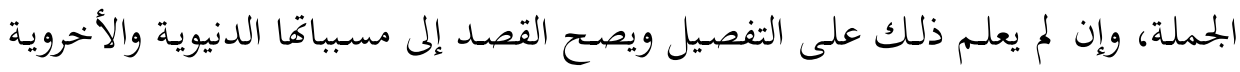

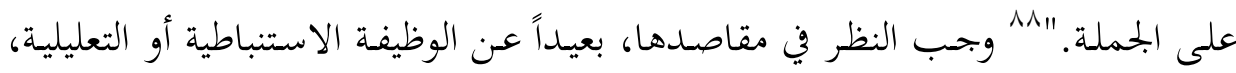

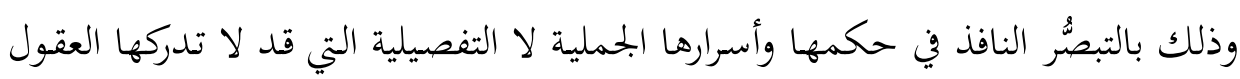

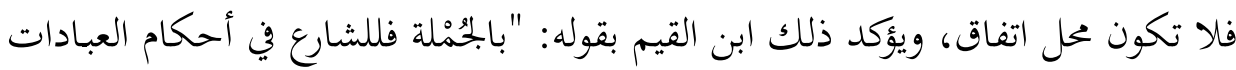

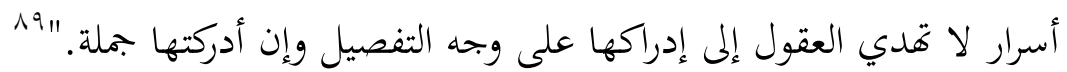
وبتحر الإشارة إلى أن عدداً من هذه الأسرار والمقاصد تتبع الاختيار الفقهي للناظر

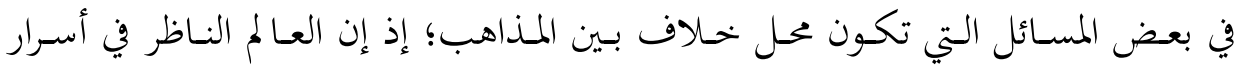

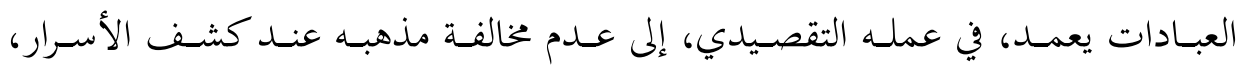

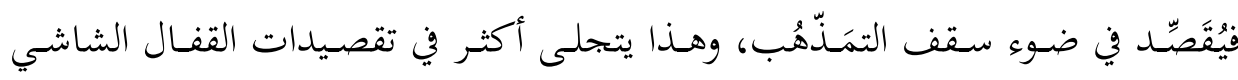

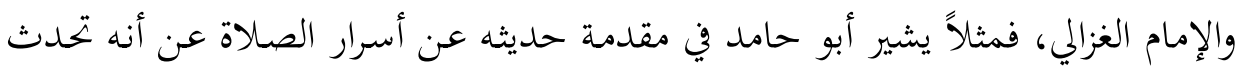

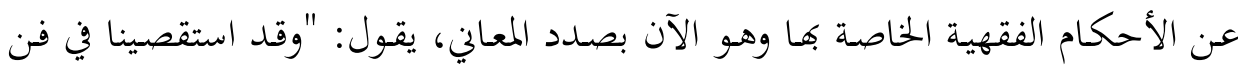

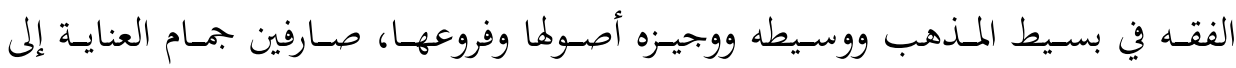

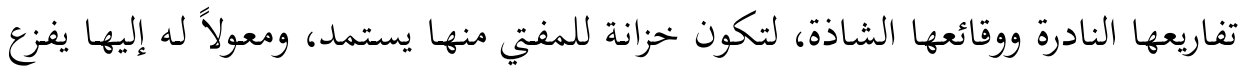

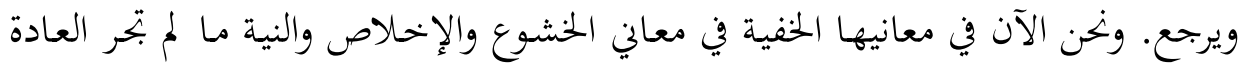

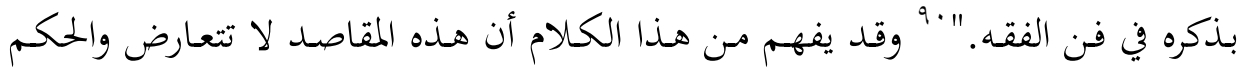

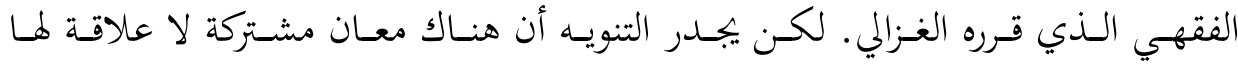
بالتمذهب الفقهي، بل معظمها كذلك.

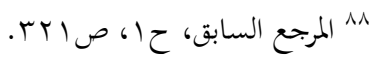
9^^ ابن القيم، حممد بن أبي بكر . إعلام الموقعين عن رب العالمين، تحقيق: طه عبد الرؤوف سعد، بيروت: دار 


\section{r. r تطبيقات لتقصيد العبادات: الصلاة أنموذجاً:}

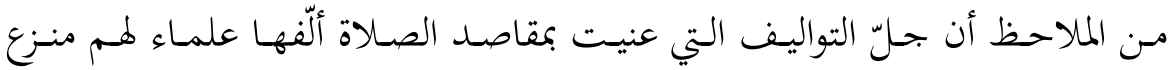

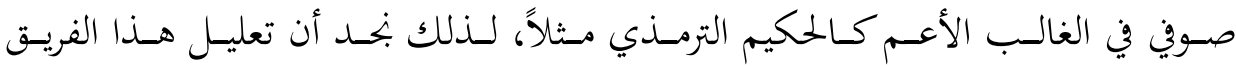

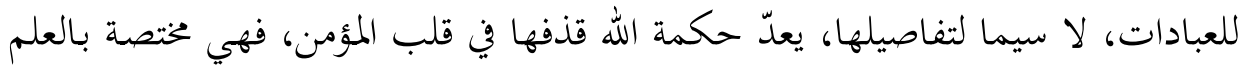

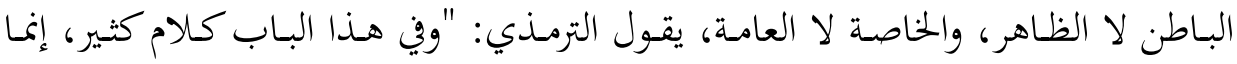

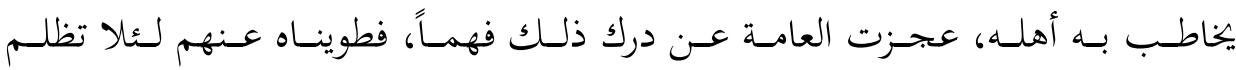

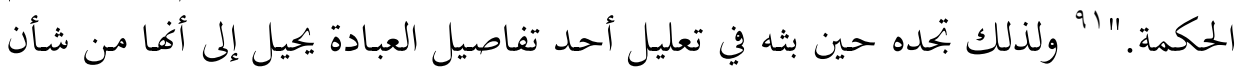

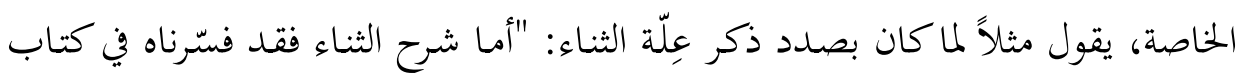

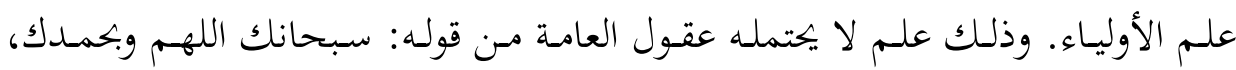

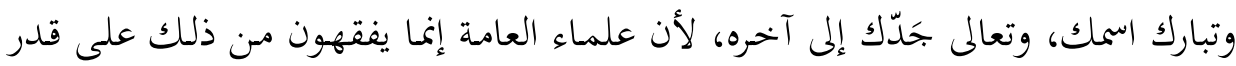

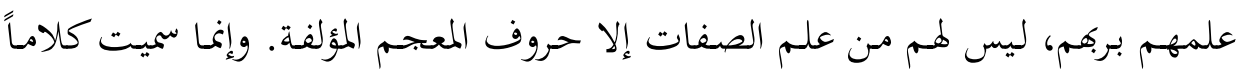

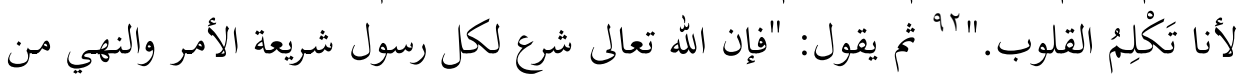

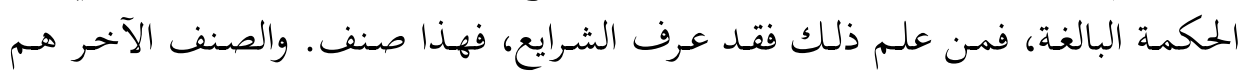

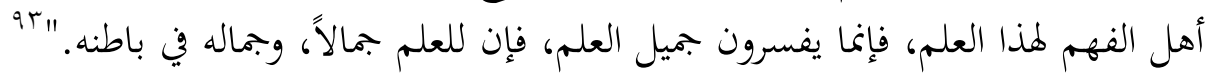

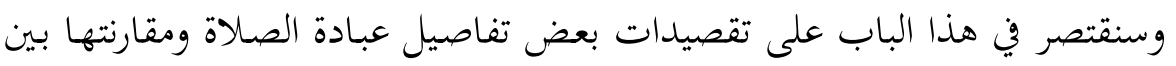

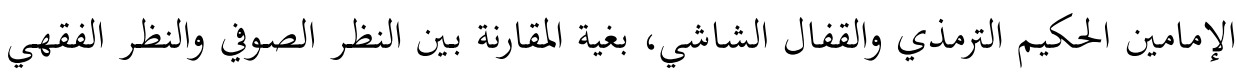

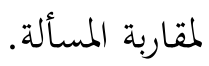

\section{أ. تقصيد العبادات عند الحكيم الترمذي:؟ 9}

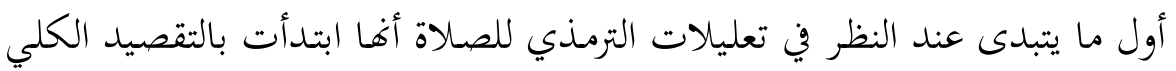

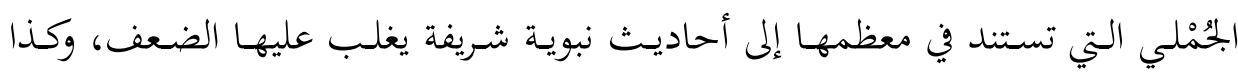
"9 الترمذي، أبو عبد الله. إثبات العلل، تحقيق: خالد الزهري، الرباط: كلية الآداب والعلوم الإنسانية، طا،

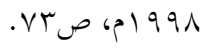

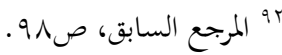

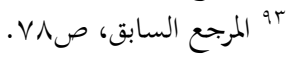

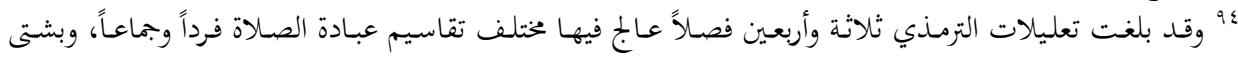

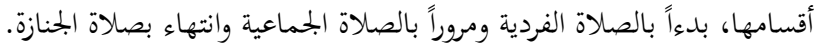




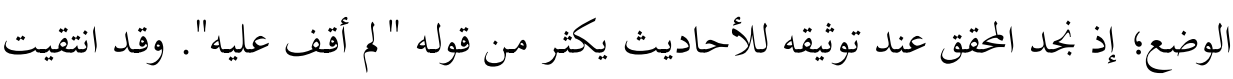

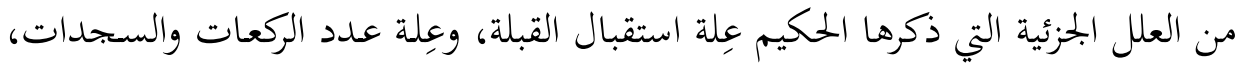
وهذا تفصيلها.

\section{عِلة استقبال القبلة: - م}

عقد الحكيم الترمذي فصلاً وسمه بـ"ذكر علة استقبال القبلة وقت الصلاة" واستهله

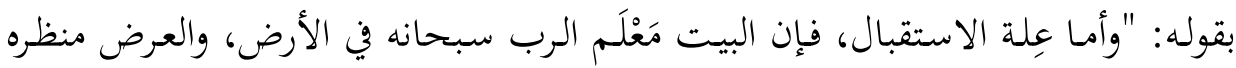
ومظهره في العلو، فاستقبال المنظر والمظهر والاستلقاء على القفا كذلك قيل في الروايات:

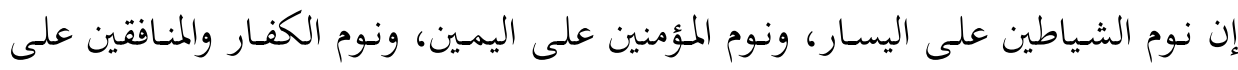

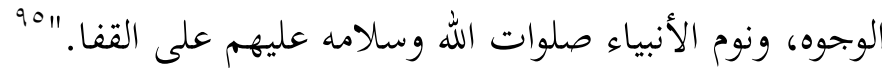

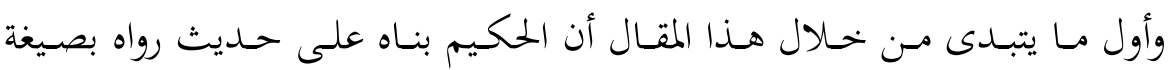

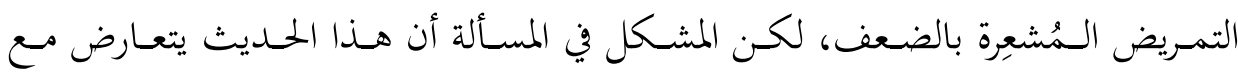
الصحيح الذي ثبت فيه استحباب النوم على اليمين، كما قال النبي في

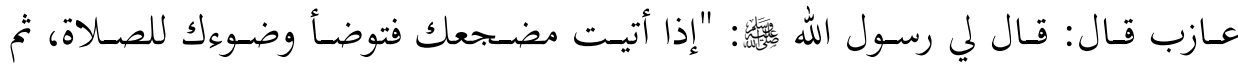
اضطجع على شقك الأيمن،" "جه وفي رواية أخرى: "فتوسّد يمينك".

\section{عِلة عدد الركعات والسجدات:}

وهذه من العِلل التفصيلية الجزئية التي أوردها الحكيم الترمذي، يقول: "وأما عِلة عدد

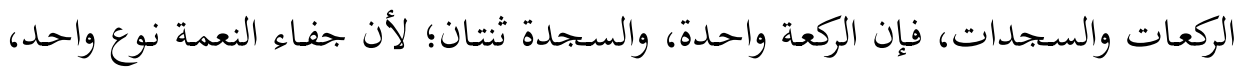
والذنب نوعـان: تضسييع الفريضـة، والوثوب في الحرمات؛ لأنه أمر وفهي. فهما واحها نوعـان:

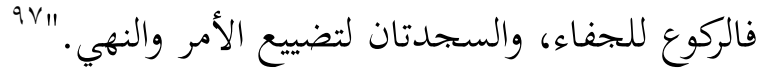

والذي يظهر أن ربط الركعة الواحدة بجفاء النعمة لا دليل عليه مـن نص أو عقل، لذلك كانت سمة هذا التقصيد التكلُف الظاهر لانعدام وجهد المناسبة.

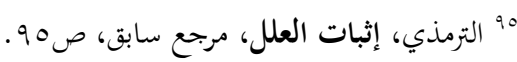

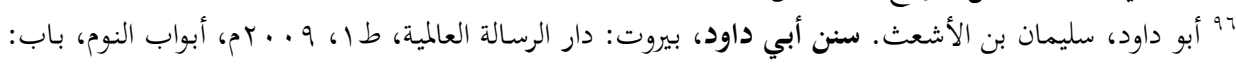

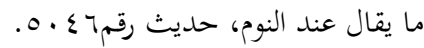

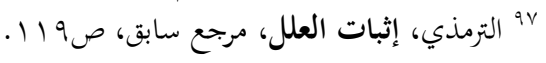




\section{ب. تقصيد العبادات عند القفال الشاشي:}

يشـير القفــال الشاشـي في مقدمـة كتابـه "عحاسـن الشـريعة" إلى أن العِلَـة في الشيء

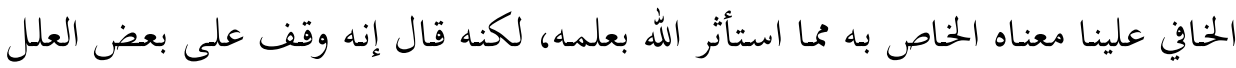

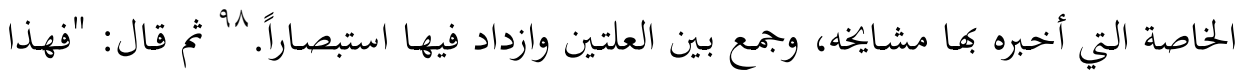

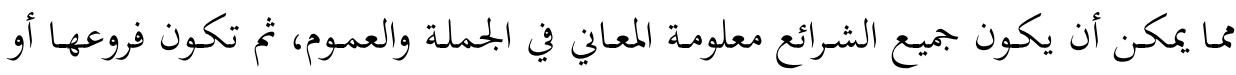
فروع كثير منها بحهول المعاني، بل الأمر فيها هكذا لإخفائه، وسنقول فيه إن شـاء الله تعالى.

وقد ذكر أن الصلاة "جملة معناهـا التعظيم للخالق بـأنواع حركات التذلل شكراً له

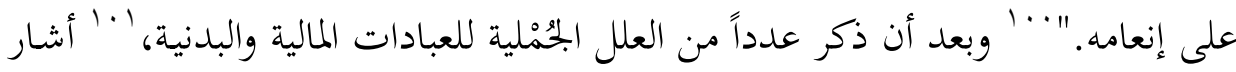
إلى أن كثيراً مـن تفاصـيل العبـادات يخفى سـره، يقـول: "والـذي يبقى وراء هــا هـو مـا يدخل في التفصيل، وكثير مـن ذلك يعقل جنسـه، وكثير منه يخفى الوجسه فيه، كأعـداد

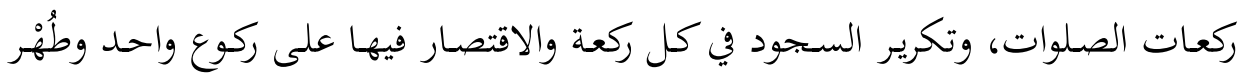

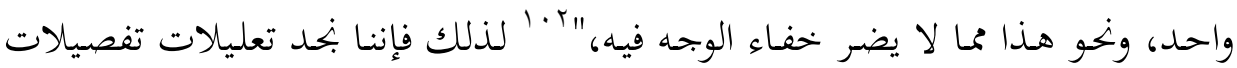
العبادة تقل في كتاب القفال مقارنة بالحكيم الترمذي، لكن ذلك لم يمنعه من الخوض في بعض المسائل التي لا نص فيها، وهذا مثالها.

\section{المقصد من عدد الصلوات المكتوبات:}

يقول القفال: "ثخ جعلها الله خمساً: صلاة الظهر، وصلاة العصر، وصلاة المغرب، أمان

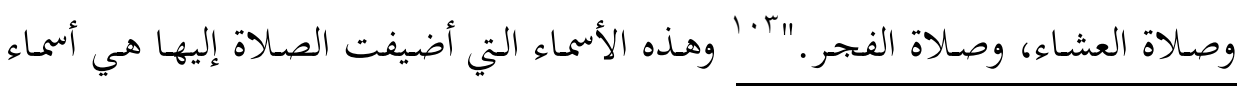
هף القفال، أبو بكر. محاسن الشريعة في فروع الشافعية، عناية: محمد علي سمك، بيروت: دار الكتب العلمية،

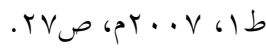

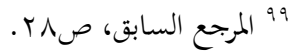

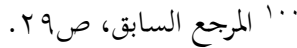

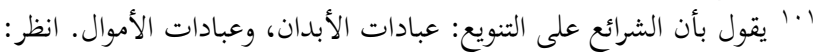

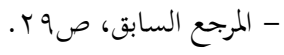

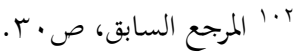

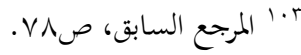


للمواقيـت؛ لأن الظهر هـو اسـم للظهيرة، وهي نصف النهار، والعصـر اسـم للعشي، والمغرب لغروب الشمس، والعشاء لدخول الليل وكمال الظلام، والفجر لانفجار الصبح،

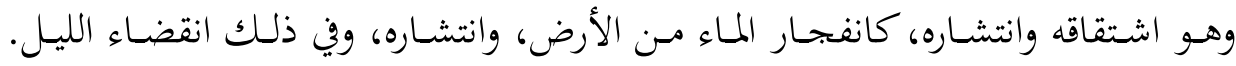

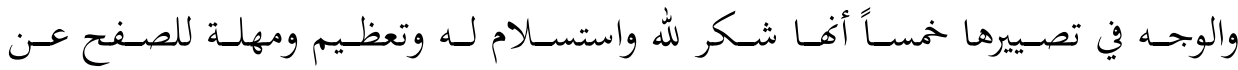

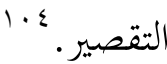

فهذه هي بعض المعاني التي ذكرها القفال، التي لا تتعارض مع واجـب التعبُّد، ولا

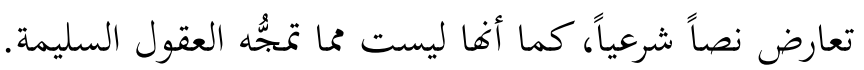
والملاحظ على تعليلات القفال الجدمْلية والتفصيلة أها تبتعد عن التوسل بالأحاديث

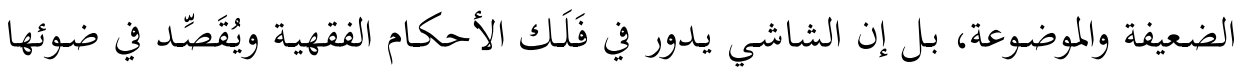
دون إيغال متكلّف، وهذا راجع بالأساس إلى التكوين الأصولي والفقهي للقفال الشاشي بالإضـافة إلى معرفته الحلديثية، فقـد قال الحاكم في شأنه: "كان أعلم أهـل مـا وراء النهر

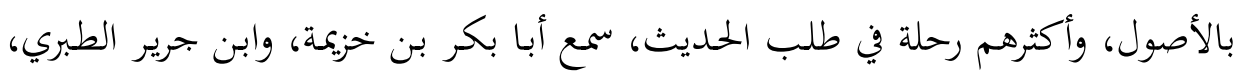

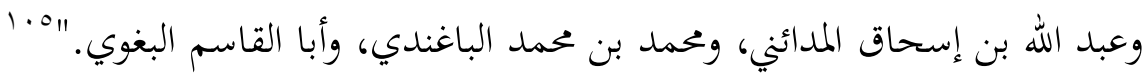
وعليه، كان لتكوين الناظر في مقاصد العبادات أثر على مقاله؛ إذ إن الناظر الأول لماكان صـوفي المنـزع قليل البضـاعة الحديثية ظهر ذلك على بعض تقصيداته، فقـد بنى

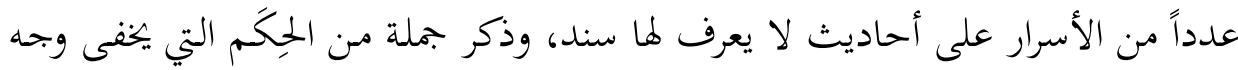

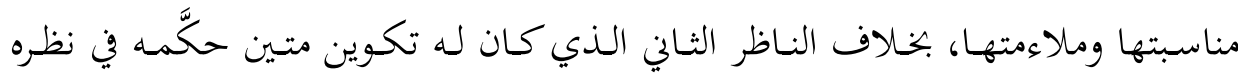
التقصيدي.

والتوغـل في التقصسيد التفصسيلي لتفاصسيل الصـلاة كعـدد ركعاتها وأوقاتها يوقـع في التكلُّف، بخلاف النظر الجُمْلي لمقاصد الصـالة الكلية والعمرانية، ودورهـا في تربية الفرد

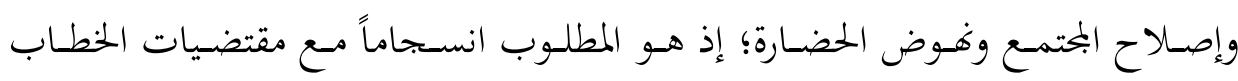
القرآي.

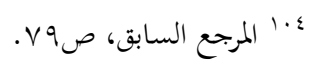

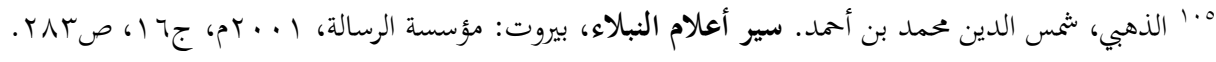




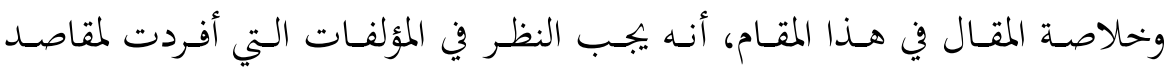

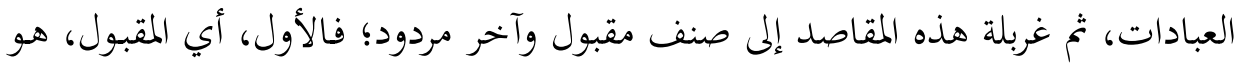

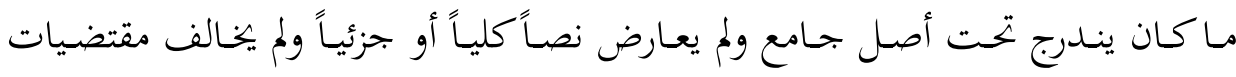

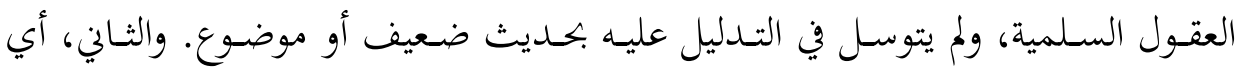

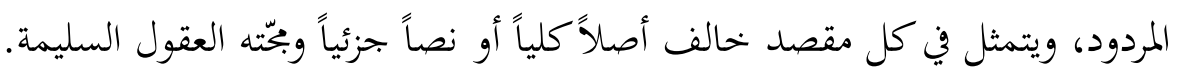

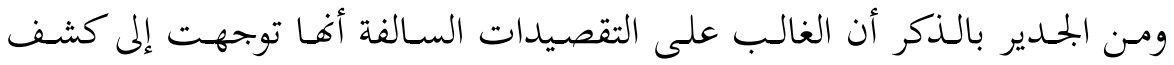

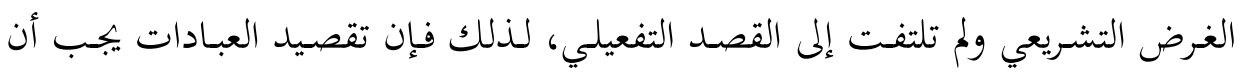
يجمع بين الأمرين في سبيل تفعيل مقاصدي للعبادة في الحياة العامة.

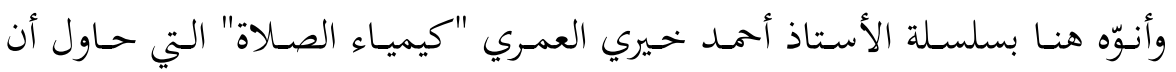

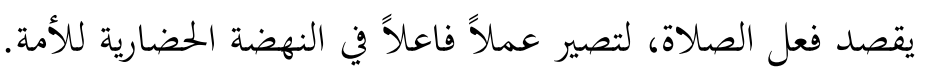

\section{خاتمة:}

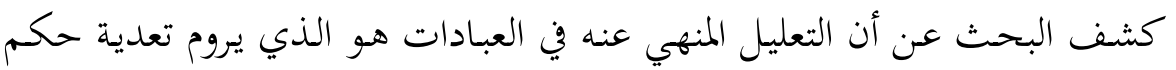

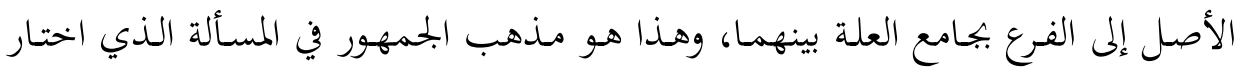

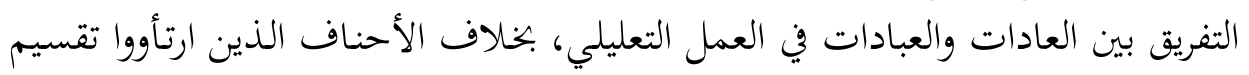
الأحكام إلى معللة وغير معللة بصرف النظر عن البحال.

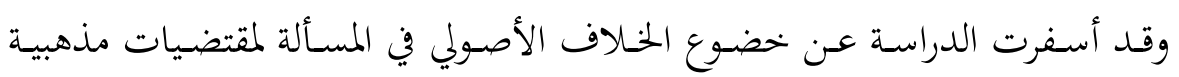

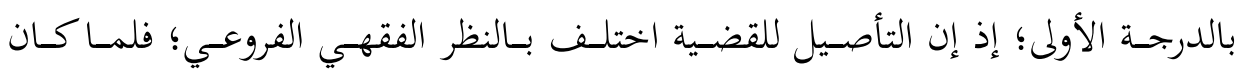

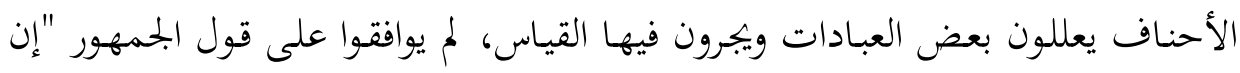

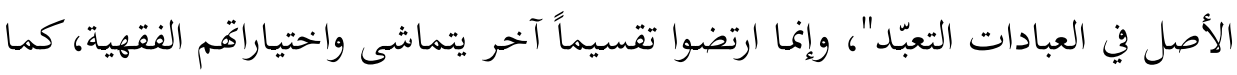

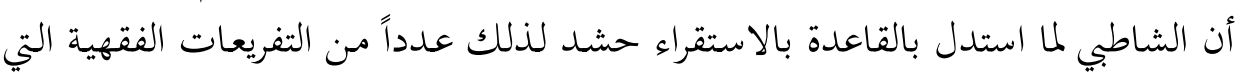

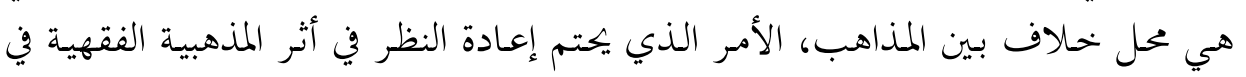
التنظير الأصولي.

وقد أبانت هذه المحاولة البحثية عن أن التعبّد لا يتعارض مع معقولية الماركية المعنى إجمالاً.

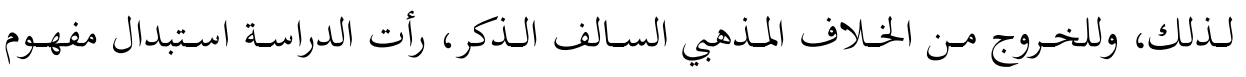


"التقصيد" بمصطلح "التعليل"، والذي يروم البحث في مقاصد العبادات وأسرارها بعيداً عن التعليلات الجزئية الخلافية، أو الأسرار الباطنة الخفية.

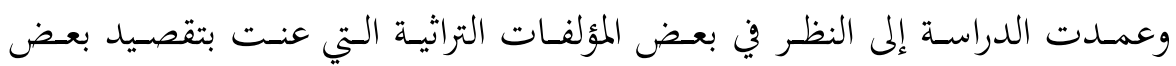

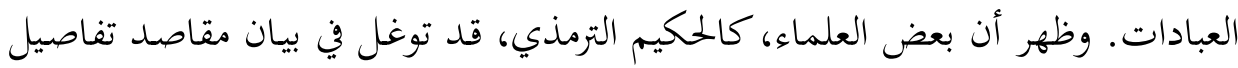

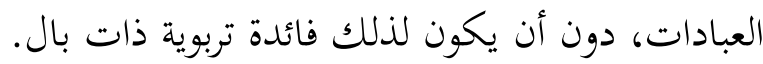

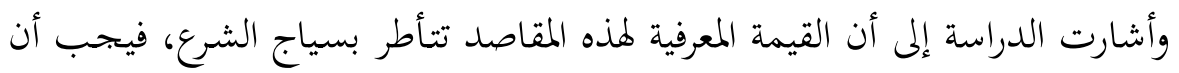
لا تصادم أصول الشرع، أو تخالف مقتضيات العقول. إلف الفيمة المعفية مله المفاصل

تعي الدراسـة أن ثمـة ضـرورة لضـبط مصطلح المقاصـد؛ إذ إن التحديـد المصطلحي

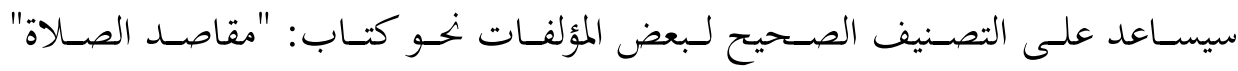

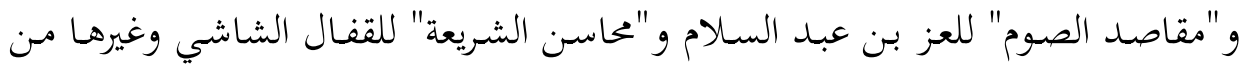
الكتب التي عُنيت بتقصيد العبادات.

ووهـن المقترحـات المفيـدة مـن أجـل تعميق النظر في مقاصـد العبـادات جـرد المقاصـ

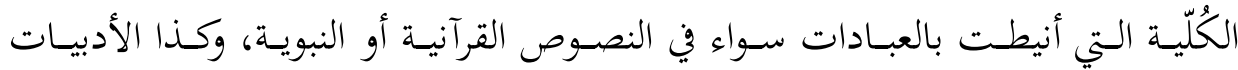

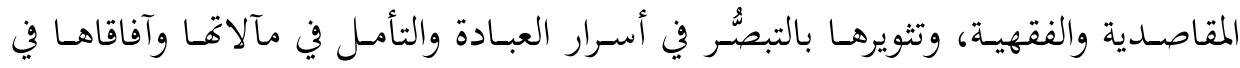

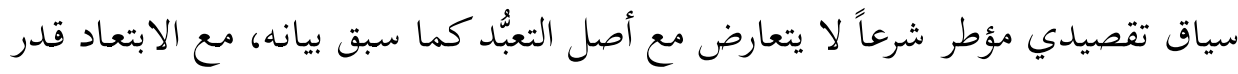

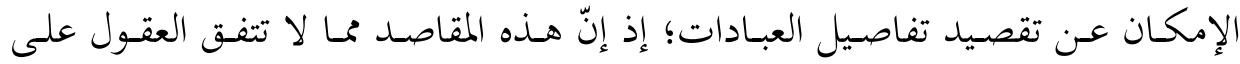
عللها، ولا ضابط يفصل بينها، كما أن الغرض وراء ذلك يخفى للأغلب، إلا من فئ فتح الله إله عليه بفتح مبين.

لذلك، فإن توجيه النظر صوب تقصيد العبادات مقدمة عملية لنشر الوعي الحِكمي

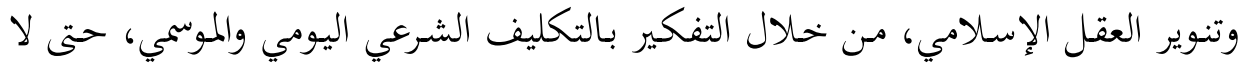

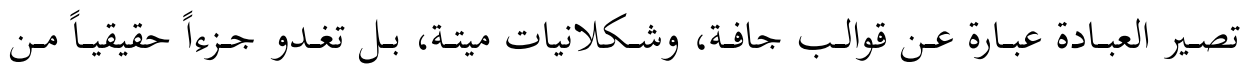

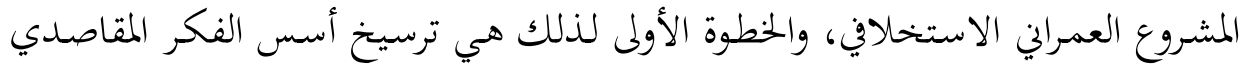

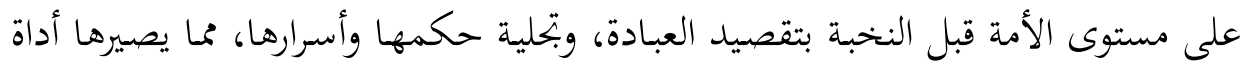

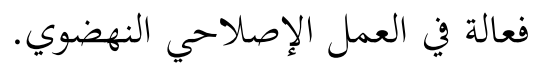

